\title{
Use of MODIS Sensor Images Combined with Reanalysis Products to Retrieve Net Radiation in Amazonia
}

\author{
Gabriel de Oliveira ${ }^{1,2, *}$, Nathaniel A. Brunsell ${ }^{2}$, Elisabete C. Moraes ${ }^{1}$, Gabriel Bertani ${ }^{1}$, \\ Thiago V. dos Santos ${ }^{3}$, Yosio E. Shimabukuro ${ }^{1}$ and Luiz E. O. C. Aragão ${ }^{1,4}$ \\ 1 Remote Sensing Division, National Institute for Space Research, 1758 Astronautas Avenue, \\ São José dos Campos, SP 12227-010, Brazil; bete@dsr.inpe.br (E.C.M.); gabrielb@dsr.inpe.br (G.B.); \\ yosio@dsr.inpe.br (Y.E.S.); laragao@dsr.inpe.br (L.E.O.C.A.) \\ 2 Department of Geography and Atmospheric Science, University of Kansas, 1475 Jayhawk Boulevard, \\ Lawrence, KS 66045, USA; brunsell@ku.edu \\ 3 Department of Soil, Water and Climate, University of Minnesota, 1991 Upper Bufford Circle, Saint Paul, \\ MN 55108, USA; dossa013@umn.edu \\ 4 College of Life and Environmental Sciences, University of Exeter, Rennes Drive, Exeter EX4 4RJ, UK \\ * Correspondence: gdo@dsr.inpe.br; Tel.: +55-12-3208-6458
}

Academic Editor: Barrett Rock

Received: 30 March 2016; Accepted: 13 June 2016; Published: 24 June 2016

\begin{abstract}
In the Amazon region, the estimation of radiation fluxes through remote sensing techniques is hindered by the lack of ground measurements required as input in the models, as well as the difficulty to obtain cloud-free images. Here, we assess an approach to estimate net radiation (Rn) and its components under all-sky conditions for the Amazon region through the Surface Energy Balance Algorithm for Land (SEBAL) model utilizing only remote sensing and reanalysis data. The study period comprised six years, between January 2001-December 2006, and images from MODIS sensor aboard the Terra satellite and GLDAS reanalysis products were utilized. The estimates were evaluated with flux tower measurements within the Large-Scale Biosphere-Atmosphere Experiment in Amazonia (LBA) project. Comparison between estimates obtained by the proposed method and observations from LBA towers showed errors between $12.5 \%$ and $16.4 \%$ and $11.3 \%$ and $15.9 \%$ for instantaneous and daily $\mathrm{Rn}$, respectively. Our approach was adequate to minimize the problem related to strong cloudiness over the region and allowed to map consistently the spatial distribution of net radiation components in Amazonia. We conclude that the integration of reanalysis products and satellite data, eliminating the need for surface measurements as input model, was a useful proposition for the spatialization of the radiation fluxes in the Amazon region, which may serve as input information needed by algorithms that aim to determine evapotranspiration, the most important component of the Amazon hydrological balance.
\end{abstract}

Keywords: Amazon region; net radiation; MODIS sensor; GLDAS data; LBA project

\section{Introduction}

The Amazon region concentrates the largest rainforest in the world, which is characterized by a high amount of natural resources and for its high biodiversity of plants and animal species [1,2]. It encompasses a large area and is positioned in the tropics, where the energy exchange between the land surface and the atmosphere is at a maximum [3]. This region, which is a major source of heat and water vapor for the global atmosphere, has been the focus of attention due to the effects that large-scale deforestation can cause on local, regional, and global climate [4,5].

Radiative processes occurring on land surface are of a remarkable importance for the redistribution of moisture and heat in soil and the atmosphere [6]. Net radiation ( $\mathrm{Rn})$ is the difference between 
incoming and outgoing radiation fluxes (shortwave and longwave) at the Earth's surface and drives, among others, the processes of photosynthesis and evapotranspiration [7]. It is a key variable for the estimation of surface energy balance and is used for a wide range of applications including hydrology, climate research, weather prediction, and agricultural meteorology [8,9]. Given the importance of physical and biological phenomena involving radiation flux exchanges, it is necessary to know these variables across both temporal and spatial scales, which allows for the improved understanding of land surface processes $[10,11]$.

Since the early 1980s, several micrometeorological experiments have been conducted involving the collection of continuous data in Amazonia. The Amazonian Research Micrometeorological Experiment (ARME) (1983-1985) aimed to acquire information to calculate rainforest evapotranspiration rates [12]. The Amazonian Boundary Layer Experiment (ABLE) (1985-1987) was conducted in order to collect data about the structure of the atmosphere in the Amazon region [13]. The Anglo Brazilian Amazonian Climate Observational Study (ABRACOS) (1991-1995) aimed to obtain measurements of energy fluxes under the conditions of forest and pasture [14]. The 2014-2015 Green Ocean Amazon Experiment (GOAmazon) was designed to enable the study of how aerosols and surface fluxes influence cloud cycles under clean conditions, as well as how aerosol and cloud life cycles are influenced by pollutant outflow from a tropical megacity [15]. Currently, the primary source of ground data in the Amazon region refers to the Large-Scale Biosphere-Atmosphere Experiment in Amazonia (LBA) [16]. This project was designed in 1998 with the purpose to develop the knowledge about the Amazon mainly in the fields of climate physics and biogeochemistry. The LBA has flux towers on different surfaces in the Brazilian states of Rondonia (RO), Amazonas (AM), Tocantins (TO), and Para (PA). The collected data have been used to understand the present state of the Amazon environment and its response to current disturbance [17].

However, the density of ground-based measurements in Amazonia is very sparse and given the extent of this region, it is necessary to represent the spatial variability of the surface radiation fluxes at a broader scale. Furthermore, these data are often temporarily limited, which can cause difficulty in their use in certain weather and climate modeling studies. Remote sensing data can provide high spatial and temporal coverage of the land surface [18-21]. In this sense, several studies have been carried out to estimate $\mathrm{Rn}$ and its components combining satellite imagery with meteorological data [6,22-26]. Remote sensing studies often make use of information obtained from daily images, such as surface reflectance, surface temperature, emissivity, and vegetation indices. Most of these studies use sensors on board the orbital platforms of National Aeronautics and Space Administration's (NASA) Earth Observing System (EOS) program, such as Thematic Mapper (TM-Landsat 5 satellite) and Moderate Resolution Imaging Spectroradiometer (MODIS-Terra and Aqua satellites) [20,27]. In relation to meteorological data, these studies generally make use of vapor pressure, air temperature, and incoming shortwave radiation measured from flux towers at the instant of the satellite overpass. A significant point here is that with the increase of spatial and temporal resolutions of remotely sensed images, meteorological input data to the models at reasonable temporal and spatial scales are required but irregularly available. Even though it may be possible to improve the spatial resolution of meteorological data, it is meaningful to explore different methods to retrieve the radiation fluxes at the surface. Previous studies focused on the use of reanalysis products in conjunction with satellite images to estimate $\mathrm{Rn}$ and its associated parameters rather than ground-based measurements [28-31]. An important source of these kind of data comes from the National Centers for Atmospheric Prediction (NCEP)/National Center for Environmental Research (NCAR) and Global Land Data Assimilation System (GLDAS) [32,33]. Although predictions from reanalyses are comprehensive in nature, the land surface products do have problems resulting primarily from the assimilation of data taken primarily from atmospheric profiles. Therefore, it is important to conduct analyzes about the biases and errors for the variables used in the models that aim to retrieve the surface radiation budget $[28,34]$.

The literature related to the estimation of radiation fluxes in Amazonia through remote sensing techniques is quite scarce [35,36], due by the lack of ground measurements required as input in the 
models, as well as the difficulty obtaining sufficiently cloud-free satellite images. In this context, this paper aims to propose and assess an approach to estimate net radiation and its components under all-sky conditions for the Amazon region through the Surface Energy Balance Algorithm for Land (SEBAL) model [6] utilizing only remote sensing and reanalysis data. The study period comprises 6 years, between January 2001-December 2006, and images from MODIS sensor aboard the Terra satellite and GLDAS reanalysis products are utilized. The estimates are evaluated with flux tower measurements within the LBA project.

\section{Materials and Methods}

\subsection{Study Area}

The study area is located in the Upper Tapajos and Curua-Una River basins, state of Para, northern region of Brazil, between latitudes $2.19^{\circ} \mathrm{S}$ and $5.18^{\circ} \mathrm{S}$ and $56.67^{\circ} \mathrm{W}$ and $53.15^{\circ} \mathrm{W}$ (Figure 1). The study area covers $74,190 \mathrm{~km}^{2}$, with an average elevation of $98 \mathrm{~m}$, ranging between 7 and $297 \mathrm{~m}$. The predominant climate is the AmW (Köeppen classification) [37], with an annual mean precipitation of $\sim 2000 \mathrm{~mm}$ and an annual mean air temperature of $\sim 26^{\circ} \mathrm{C}$ [38]. The region has well-defined dry and wet seasons. The wet season is from January to June and the dry season lasts from July through December [39]. Soils in the region are classified mainly as dystrophic yellow latosol, with high content of clay, low $\mathrm{pH}$, and low content of nutrients [40,41]. The main natural vegetation type in the study area is the dense forest [42], which has been logged and replaced by agriculture in the past few decades. For this reason, it is possible to observe in the region extensive patches of different land cover types as pasture, secondary succession forest, etc.

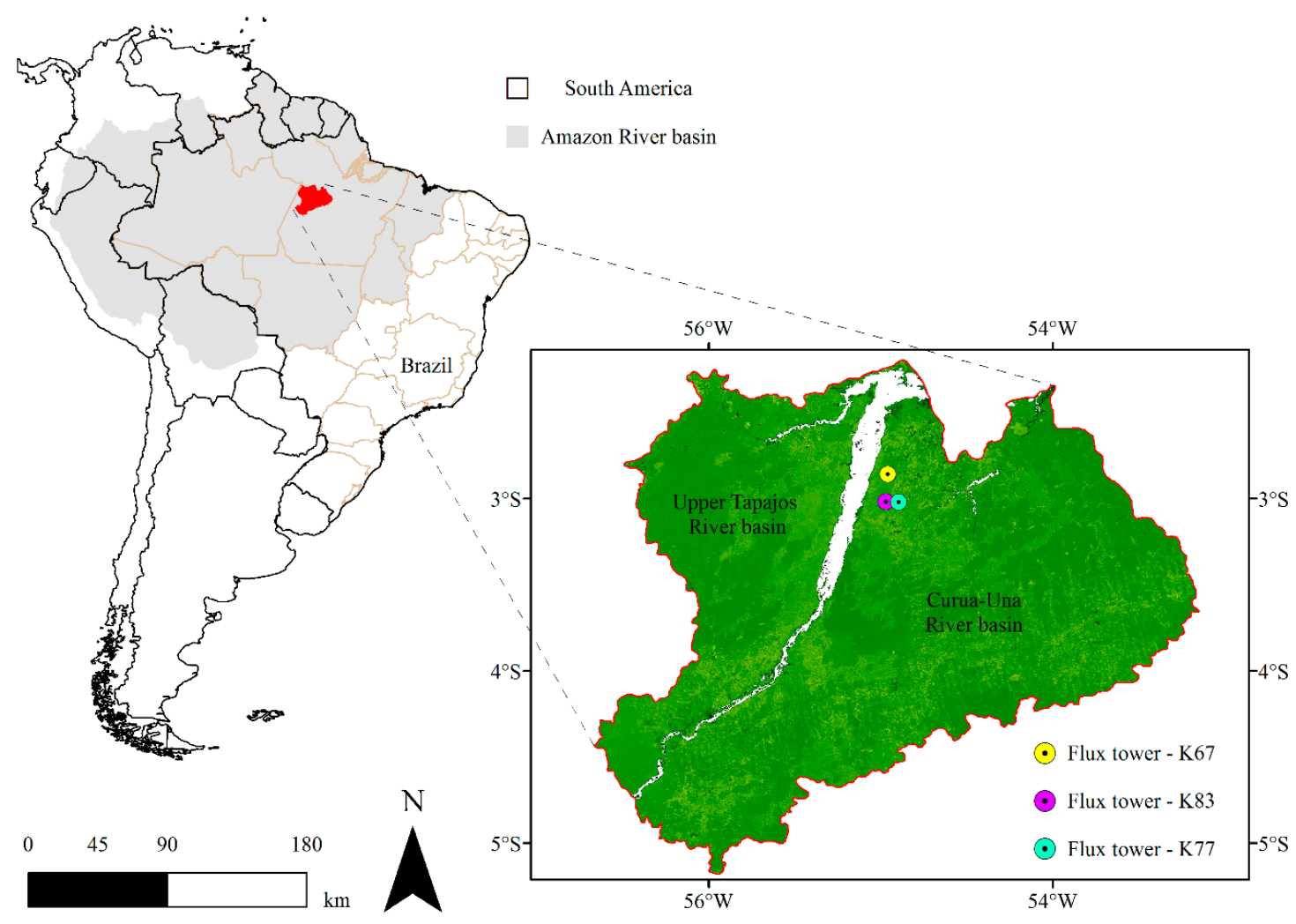

Figure 1. Map showing the study area and the spatial location of the flux tower sites used in this study.

Flux Tower Sites

Three eddy covariance flux towers sites of the LBA project (K67, K83 and K77) were used in this study (Figure 1). The sites are located in the municipality of Belterra, near the confluence of the 
Tapajos and Amazon rivers, at an average elevation of $130 \mathrm{~m}$. $\mathrm{K} 67\left(2.86^{\circ} \mathrm{S}, 54.96^{\circ} \mathrm{W}\right)$ and $\mathrm{K} 83\left(3.02^{\circ} \mathrm{S}\right.$, $54.97^{\circ} \mathrm{W}$ ) are forest experimental sites. K67 is in an undisturbed primary forest [43]. At the K83 site trees with diameter at breast height greater than $35 \mathrm{~cm}$ were selectively logged during three months beginning in September 2001 [44]. These sites have canopies with a mean height of $\sim 35-40 \mathrm{~m}$. The flux towers in K67 and $\mathrm{K} 83$ are $63 \mathrm{~m}$ and $64 \mathrm{~m}$ tall, respectively [45]. $\mathrm{K} 77$ (3.02 $\left.\mathrm{S}, 54.90^{\circ} \mathrm{W}\right)$ is in a previously forested area that had been converted to pasture. The primary forest was cleared in 1990 and the field was then planted with grass. In November 2001 the site was prepared for rice cultivation. The rice was harvested in June 2002 and the field was not replanted [46]. The mean canopy height at $\mathrm{K} 77$ is of $\sim 0-0.6 \mathrm{~m}$ and flux measurements are made on a $18 \mathrm{~m}$ tower [45]. Additional information about K67, K83, and K77 sites can be found in Gonçalves et al. [17], Saleska et al. [39], Rice et al. [47], and Miller et al. [48].

\subsection{Land Cover Data}

Land cover data from the TerraClass project (http://www.inpe.br/cra/ingles/project_research/ terraclass.php) were used in order to analyze the dynamic of net radiation under different ecosystems in the study area. This project has been developed by National Institute for Space Research (INPE)/Brazilian Agricultural Research Corporation (EMBRAPA) and aims to map the land cover especially in areas where occurred deforestation, using satellite data. According to the TerraClass classification, there are approximately 10 different land cover types inside the Upper Tapajos and Curua-Una River basins. We selected five classes for analysis, considering they are the primary ecosystems in the study area. The selected classes were: agriculture (AG), bare soil (BS), primary tropical forest (PF), pasture (PA) and secondary succession forest (SF). Using a mapping referent to 2008 [49] and two mosaics of TM-Landsat 5 images of 2001 and 2006, we selected 12 plots of $1 \mathrm{~km} \times 1 \mathrm{~km}$ within each land cover type. Plots were selected through the ArcGIS 9.3 software (Esri, Redlands, CA, USA, http://www.esri.com/software/arcgis) and from the visual inspection of TerraClass polygons superposed to the TM/Landsat 5 mosaics. Based on these plots, we extracted the long-term time series of Rn.

\subsection{Observational Data}

The ground data were collected at three flux towers located in K67, K83 and K77 LBA sites (described in Section 2.1). These data were acquired from the Oak Ridge National Laboratory (ORNL) (Oak Ridge, TN, USA, http://daac.ornl.gov/LBA/lba.shtml). Data were obtained, in general, between the years 2001 and 2006 but the time period varies from site to site. The temporal coverage of observational data at K67 and K83 sites are between January 2002-January 2006 and January 2001-March 2004, respectively. At the K77 site, observations span the period from January 2001 to December 2005. Flux tower measurements were used to validate the estimates of $\mathrm{Rn}$ and its components derived from satellite images and reanalysis products. In order to carry out this evaluation we utilized the following meteorological parameters: air temperature $\left(\mathrm{T}_{\mathrm{a}}\right)$, incoming $(\mathrm{K} \downarrow)$ and outgoing $(\mathrm{K} \uparrow)$ shortwave radiation, incoming $(\mathrm{L} \downarrow)$ and outgoing $(\mathrm{L} \uparrow)$ longwave radiation, and $\mathrm{Rn}$. The albedo $\left(\alpha_{\mathrm{s}}\right)$, which is also required for validation, is not measured directly by flux towers and was calculated as the ratio of the outgoing to the incoming shortwave radiation. The LBA flux data have been processed according to a common protocol and are aggregated to an hourly time step [45]. For comparison with instantaneous estimates, we used data corresponding to 11:00 a.m. local time in the Upper Tapajos and Curua-Una River basins region (GMT-4). This period includes the Terra satellite overpass over the study area ( 10:30 a.m. local time). Based on these 1-hour data, we have calculated the daily and consequently monthly averages. We chose not to apply gap-filling procedures to the datasets [50,51]. The quality control in the data followed a methodology that is applied to all LBA datasets and can be found in details in Gonçalves et al. [17] and Restrepo-Coupe et al. [45]. 


\subsection{MODIS Data}

Remote sensing data used in this study were derived from the MODIS sensor aboard the Terra satellite, launched in December 1999. Terra satellite crosses the study area during the daytime at approximately 10:30 a.m. local time. It should be noted that there are fewer clouds over the Amazon region in the morning in comparison with the afternoon, especially in the dry season. For this reason, it is more appropriate to use MODIS sensor images from Terra satellite instead of Aqua satellite, which passes south to north over the equator in the afternoon. The MODIS sensor has a polar orbit, a $700 \mathrm{~km}$ altitude and an imaging area of $2330 \mathrm{~km}$ [52]. The sensor has 36 spectral bands spanning $405-14385 \mathrm{~nm}$ wavelengths. The spatial resolution at nadir varies with spectral band: $250 \mathrm{~m}$ (bands 1-2) (visible), $500 \mathrm{~m}$ (bands 3-7) (visible/medium infrared), and $1 \mathrm{~km}$ (bands 8-36) (visible/thermal infrared). The geometric characteristics of this sensor ensure high accuracy in multi-spectral registration, multi-temporal registration, and absolute geolocation [53].

The MODIS datasets were obtained from the United States Geological Survey (USGS) (Sioux Falls, SD, USA, https://lpdaac.usgs.gov/data_access/data_pool). We used the following Version 5 products: MOD09Q1, MOD09A1, MOD11A2, and MOD44W. MOD09Q1 provides surface reflectance for bands 1 and 2 in an 8-day composite at $250 \mathrm{~m}$ resolution. MOD09A1 provides reflectance values for bands 3, 4, 5, 6 and 7 in an 8-day composite at $500 \mathrm{~m}$ resolution. MOD11A2 gives land surface temperature in an 8-day composite at $1 \mathrm{~km}$ resolution over cloud-free land areas (clouds are masked with the MODIS cloud mask data product (MOD35L2)). MOD44W corresponds to land-water mask at $250 \mathrm{~m}$ resolution. The images used encompassed the h12v09 tile, which covers the Upper Tapajos and Curua-Una River basins in the Amazon region, from January to December, over 6 years (2001-2006). First, MODIS images were projected to a geographic coordinate system (lat./long.) based on the WGS 84 datum, spatially resampled to $1 \mathrm{~km}$ using the nearest neighborhood method according the proposition of Wolfe et al. [54], and converted to the GeoTIFF format using the MODIS Reprojection Tool (MRT) (USGS, https://lpdaac.usgs.gov/tools/modis_reprojection_tool). Then, a number of steps were undertaken including clipping of the study area, multiplication by scale factors, application of the land-water mask over MOD09Q1, MOD09A1 and MOD11A2 datasets, extraction of the cloud mask from MOD11A2 product and application over MOD09Q1 and MOD09A1 datasets.

\subsection{Reanalysis Data}

Reanalysis products from GLDAS were used in this study. The GLDAS project has been developed jointly by scientists at the NASA/Goddard Space Flight Center (GSFC) and the National Oceanic and Atmospheric Administration (NOAA)/NCEP. GLDAS is a global, low resolution, offline (uncoupled to the atmosphere) terrestrial modeling system that integrates satellite and ground-based observational data in order to produce optimal fields of land surface states and fluxes in near real time [33].

The GLDAS datasets were acquired from the NASA Goddard Earth Sciences Data and Information Services Center (GESDISC, Greenbelt, MD, USA, http://disc.sci.gsfc.nasa.gov/hydrology/dataholdings). The GLDAS products used in this paper referred to the Version 1 are incoming shortwave radiation and air temperature. These products are generated with the Noah land Surface model [55] at a resolution of $0.25^{\circ}$ and a temporal frequency of three hours (12:00 a.m., 3:00 a.m., 6:00 a.m., 9:00 a.m., 12:00 p.m., 3:00 p.m., 6:00 p.m., 9:00 p.m.). For the incoming shortwave radiation, we used the data available every three hours (8 files/day) for the entire study period. Concerning the air temperature, we only used the data corresponding to 3:00 p.m., which refers to 11:00 a.m. local time in the Upper Tapajos and Curua-Una River basins region (GMT-4). This period includes the instant of Terra satellite overpass over the study area ( 10:30 a.m. local time). Preprocessing of the data included clipping of the study area, projection to a geographic coordinate system (lat./long.) based on the WGS 84 datum, spatial resampling to $1 \mathrm{~km}$ using the nearest neighbor method, application of the land-water mask and the cloud mask extracted from MODIS products. It should be noted that incoming shortwave radiation and air temperature products were averaged for every 8-day period according to the dates of the MODIS composite products in each year. Then, the composite images were stored in the GeoTIFF 
format. All procedures involving the GLDAS products were conducted aiming that they were spatially and temporally consistent with the MODIS datasets. This consistency is necessary to properly estimate the net radiation and components considering our approach.

\subsection{Estimation of Net Radiation}

The physically based SEBAL model [6] was used to calculate Rn and its components in the Upper Tapajos and Curua-Una River basins. The SEBAL model is comprised of 25 computational sub-models that computes evapotranspiration and other components of the energy balance. The components of the surface energy balance are estimated in the following sequence: $R n$, ground heat $(G)$, sensible heat $(\mathrm{H})$, and latent heat $(\lambda \mathrm{E})$. In its original formulation, the model requires as input ground-based meteorological data in addition to satellite images. Therefore, to retrieve Rn SEBAL needs field measurements of air temperature and incoming shortwave radiation, and to obtain evapotranspiration estimates the model needs field measurements of wind speed [56,57].

In the following, we present the theoretical basis of SEBAL to estimate the net radiation as well as some adaptations incorporated in the model for eliminating the need of ground data as input. The SEBAL model was implemented using the ERDAS Imagine 2014 (Leica Geosystems, Heerbrugg, Switzerland, http:/ / leica-geosystems.com/) spatial modeler function. The instantaneous $\mathrm{Rn}\left(\mathrm{W} \cdot \mathrm{m}^{-2}\right)$ ( 10:30 a.m. local time) was calculated using the relationship proposed by Bastiaanssen et al. [6]:

$$
\mathrm{Rn}=\left(1-\alpha_{\mathrm{s}}\right) \mathrm{K} \downarrow+\mathrm{L} \downarrow-\mathrm{L} \uparrow-\left(1-\varepsilon_{\mathrm{s}}\right) \mathrm{L} \downarrow
$$

where $\alpha_{\mathrm{s}}$ is the surface albedo, $\mathrm{K} \downarrow\left(\mathrm{W} \cdot \mathrm{m}^{-2}\right)$ is the incoming shortwave radiation at surface, $\mathrm{L} \downarrow$ $\left(\mathrm{W} \cdot \mathrm{m}^{-2}\right)$ is the incoming longwave radiation from the atmosphere, $\mathrm{L} \uparrow\left(\mathrm{W} \cdot \mathrm{m}^{-2}\right)$ is the outgoing longwave radiation emitted from the surface to the atmosphere, and $\varepsilon_{\mathrm{s}}$ is the surface emissivity.

The surface albedo $\left(\alpha_{\mathrm{s}}\right)$ was determined using the algorithm developed by Liang [58]:

$$
\alpha_{\mathrm{s}}=0.160 \rho_{1}+0.291 \rho_{2}+0.243 \rho_{3}+0.116 \rho_{4}+0.112 \rho_{5}+0.081 \rho_{7}-0.0015
$$

where $\rho_{\mathrm{i}}(\mathrm{i}=1,2, \ldots, 7)$ is the surface reflectance for bands 1 through 7 of the MODIS sensor.

To obtain the surface emissivity $\left(\varepsilon_{s}\right)$, it was necessary to calculate three vegetation indices: the normalized vegetation difference index (NDVI), the soil adjusted vegetation index (SAVI), and the leaf area index $(\mathrm{LAI})\left(\mathrm{m}^{2} \cdot \mathrm{m}^{-2}\right)$. The NDVI was calculated as the difference between near-infrared and red reflectance values normalized over the sum of the two [59]:

$$
\mathrm{NDVI}=\frac{\rho_{2}-\rho_{1}}{\rho_{2}+\rho_{1}}
$$

The SAVI was computed as follows:

$$
\text { SAVI }=\frac{(1+\delta)\left(\rho_{2}-\rho_{1}\right)}{\left(\delta+\rho_{2}+\rho_{1}\right)}
$$

where $\delta$ is an adjustment factor used to compensate for the influence of varying soil backgrounds on the measured plant index and we are using the typically assigned value of $\delta=0.5$ [60].

To obtain the LAI, we used the method of Allen et al. [56].

$$
\mathrm{LAI}=\frac{\ln \left(\frac{0.69-\mathrm{SAVI}}{0.59}\right)}{0.91}
$$

The $\varepsilon_{\mathrm{s}}$ was estimated from the LAI as:

$$
\varepsilon_{\mathrm{S}}=0.95+0.01 \mathrm{LAI}
$$


Equation (6), however, is only valid for pixels with NDVI values greater than zero. For the pixels with NDVI values less than zero, we assigned $\varepsilon_{\mathrm{s}}=0.985$ [56].

In the SEBAL model, $\mathrm{K} \downarrow$ is calculated as a function of the solar constant, the solar zenith angle, the relative distance between the Earth and the Sun, and the atmospheric transmissivity at the instant of the satellite overpass [56]. In our approach, we used raster data from GLDAS related to the incoming shortwave radiation for 11:00 a.m. local time.

The incoming longwave radiation from the atmosphere $(L \downarrow)$ was estimated by the Stefan-Boltzmann law:

$$
\mathrm{L} \downarrow=\varepsilon_{\mathrm{a}} \sigma \mathrm{T}_{\mathrm{a}}{ }^{4}
$$

where $\varepsilon_{\mathrm{a}}$ is the atmospheric emissivity, $\sigma$ is the Stefan-Boltzmann constant $\left(5.67 \times 10^{-8} \mathrm{~W} \cdot \mathrm{m}^{-2} \cdot \mathrm{K}^{-4}\right)$, and $T_{a}$ is the near surface air temperature $(K)$. In the original formulation of SEBAL, the information about $\mathrm{T}_{\mathrm{a}}$ is obtained from a micrometeorological tower located within the study area. In this study, aiming to eliminate the needed of observational measurements to estimate net radiation and its components, we used air temperature data obtained from GLDAS for 11:00 a.m. local time.

The atmospheric emissivity $\left(\varepsilon_{\mathrm{a}}\right)$ was estimated through an empirical formula proposed by Bastiaanssen et al. [6]:

$$
\varepsilon_{\mathrm{a}}=0.85(-\ln \tau)^{0.09}
$$

where $\tau$ is the one way atmospheric transmissivity, computed using the equation described by Allen et al. [56]:

$$
\tau=0.75+2 \times 10^{-5} \mathrm{z}
$$

where $\mathrm{z}$ is the elevation $(\mathrm{m})$. Usually, the authors consider $\mathrm{z}$ the elevation in the pixel where the micrometeorological tower is located which provides ground-based data for the model. We assigned the average elevation of the study area for $\mathrm{z}$, which corresponds to $98 \mathrm{~m}$. We computed this average through the GTOPO30 global digital elevation model (DEM, https://lta.cr.usgs.gov/GTOPO30).

The outgoing longwave radiation emitted from the surface to the atmosphere $(\mathrm{L} \uparrow)$ was estimated using the following equation:

$$
\mathrm{L} \uparrow=\varepsilon_{\mathrm{S}} \sigma \mathrm{T}_{\mathrm{S}}^{4}
$$

where $T_{\mathrm{S}}$ is the surface temperature $(\mathrm{K})$.

After we obtained the instantaneous net radiation, we estimated the daily net radiation $\left(\mathrm{Rn}_{24 \mathrm{~h}}\right)$ $\left(\mathrm{W} \cdot \mathrm{m}^{-2}\right)$ adopting a simplified formula described in Bastiaanssen et al. [57]:

$$
\mathrm{Rn}_{24 \mathrm{~h}}=\left(1-\alpha_{\mathrm{s}}\right) \mathrm{K} \downarrow_{24 \mathrm{~h}}-110 \tau
$$

where $\mathrm{K} \downarrow_{24 \mathrm{~h}}$ is the daily incoming shortwave radiation $\left(\mathrm{W} \cdot \mathrm{m}^{-2}\right.$ ). The SEBAL model, in its conception, uses $\mathrm{K} \downarrow_{24 \mathrm{~h}}$ measured from flux towers. In the present study the value of $\mathrm{K}_{\downarrow_{24}}$ used as input in SEBAL was obtained for each day through the average of the GLDAS products available every three hours (8 files/day).

The model was run for each 8-day period from January 2001-December 2006. That is, the model was run 46 times a year totaling 276 round over the whole period. Therefore, the model estimated 276 images for each variable. The atmospheric conditions over the Amazon are often cloudy, especially in the wet season, and therefore many of these images resulted in few cloud free pixels. In order to minimize this problem and provide spatially consistent surface radiation budget maps over the study area, we generated monthly composites of each variable. To obtain the composites for each month, we used four 8-day images (corresponding to 32 days). To select which images would compose each month, we took into account the composition dates of the MODIS 8-day products in a normal (non-leap) year. Then, we calculated the average of the 8-day images for those monthly periods ignoring the cloud mask values (NoData). This means that all input cells at each location, including those with a value of NoData, were used in determining the statistic. 


\subsection{Validation}

The surface radiation budget estimates and reanalysis data were compared with LBA flux tower measurements to evaluate the performance of our approach. The estimated values were extracted from one pixel $(1 \mathrm{~km} \times 1 \mathrm{~km})$ centered on each flux tower $(\mathrm{K} 67, \mathrm{~K} 83$ and $\mathrm{K} 77)$ [61]. It is important to highlight that K67, K83 and K77 sites comprise the conditions of primary tropical forest, secondary succession forest and agriculture, respectively. These represent the most important terrestrial ecosystems in the Amazon. Therefore, we assume that they can represent the average environmental conditions of the study area. Four indices, including the correlation coefficient $\left(\mathrm{r}^{2}\right)$, bias (Equation (12)), root mean square error (RMSE) (Equation (13)) and mean relative error (MRE) (Equation (14)), were used to assess the accuracy of the estimations:

$$
\begin{gathered}
\text { bias }=\frac{\left(\sum X_{\text {mod }}-X_{\text {obs }}\right)}{N} \\
\text { RMSE }=\sqrt{\frac{\sum\left(X_{\text {obs }}-X_{\text {mod }}\right)^{2}}{N}} \\
\text { MRE }=\frac{100}{N} \sum\left|\frac{X_{\text {mod }}-X_{\text {obs }}}{X_{\text {obs }}}\right|
\end{gathered}
$$

where $X_{o b s}$ is the flux tower observation, $X_{\text {mod }}$ is the modelled value, and $N$ is the number of samples. The $r^{2}$ is used to determine the strength of the linear relationship between the estimates and measurements. Bias is a measure of how a modelled value deviates from the true value, indicating if there is under or overestimation. The RMSE is the overall error in the predictions relative to the actual measured value. The MRE is a measure of prediction accuracy, expressed as a percentage. These statistical techniques are commonly used for comparing pairs of variables and allow evaluating the error of data $[62,63]$.

\section{Results and Discussion}

\subsection{Spatio-Temporal Dynamics of the Components of Net Radiation over the Upper Tapajos and Curua-Una} River Basins

Net radiation is the sum of all gains and losses of radiation (including shortwave and longwave) to and from the surface. In this section, we address the spatial and temporal behavior of the following components of radiation budget in the study area: incoming shortwave radiation, albedo, incoming longwave radiation, outgoing longwave radiation and net radiation.

\subsubsection{Incoming Shortwave Radiation}

The highest incidence of solar radiation throughout the year took place in the central and eastern

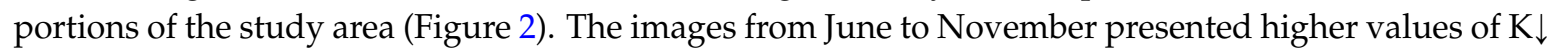
in comparison with the images from December to April. This pattern is attributed to the characteristics of the dry and wet seasons in the region. The dry season in the eastern part of the Amazon can vary interannually in terms of length and intensity, but typically occurs between July and December. The wet season typically occurs between January and June [39]. It is important to note that the Amazon region, located between $5^{\circ} \mathrm{N}$ and $10^{\circ} \mathrm{S}$, receives the highest amounts of solar radiation at the top of atmosphere during the wet season but it is in the dry season that the highest amounts of solar radiation actually reach the earth's surface [64]. According to Malhi et al. [65], the seasonal change in cloud cover is the main determinant of incoming shortwave radiation in the Amazon, with solar angle playing a secondary role. Therefore, the decreasing cloud cover during the dry season is directly associated with the increase in incoming shortwave radiation. It is important to note that greenhouse gases and smoke aerosols produced during the annual biomass-burning season in Amazonia have a substantial effect on the regional radiation budget and climate. These gases and aerosols may absorb and scatter solar radiation, leading to reductions in total solar radiation reaching the surface [66]. This 
reduction can cause, consequently, a decrease on the energy available at surface (Rn) to be used for the evapotranspiration process, for example. The biomass burning in the Amazon region usually occurs during the dry season (August and September), with the concentration of gases and aerosols peaking in this time of the year. Thus, depending on the quantity of fire burning events during the annual biomass-burning season, it can occur significant oscillations in the incidence of solar radiation between the driest periods of different years [67].
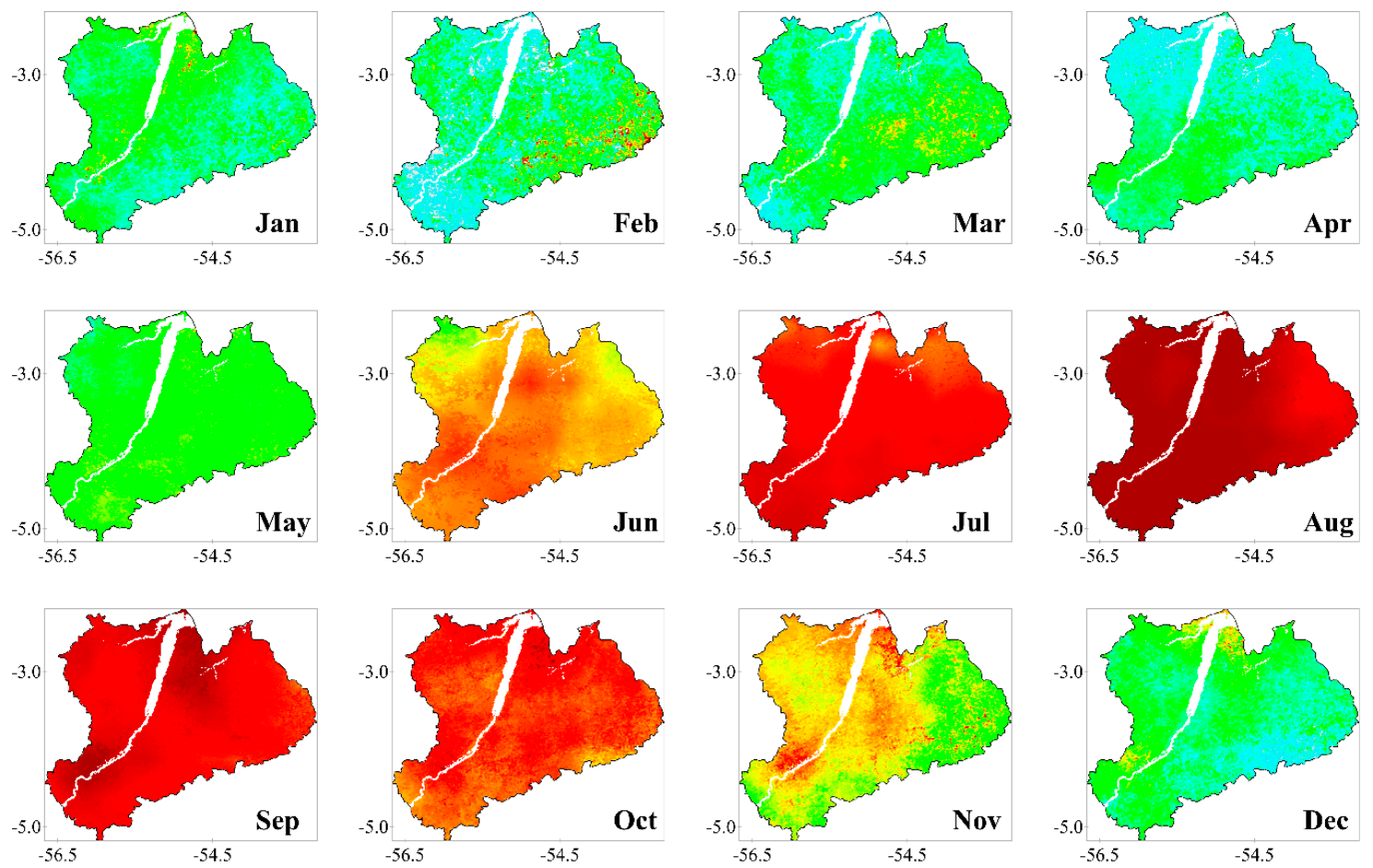

Incoming Shortwave Radiation ( $\left.\mathrm{W} \mathrm{m}^{-2}\right)$

No Data
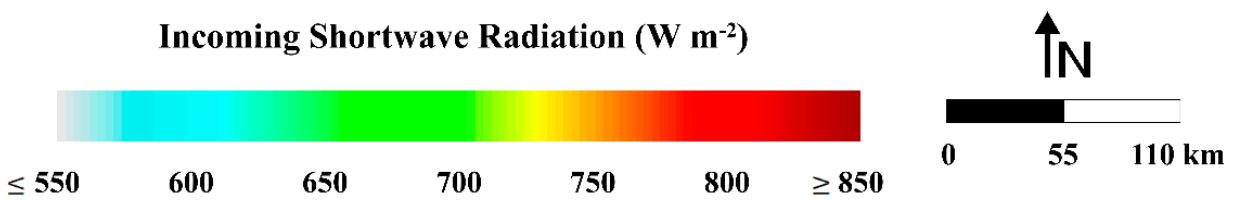

Figure 2. Monthly averages of incoming shortwave radiation $\left(\mathrm{W} \cdot \mathrm{m}^{-2}\right.$ ) (months of January (Jan), February (Feb), March (Mar), April (Apr), May (May), June (Jun), July (Jul), August (Aug), September (Sep), October (Oct), November (Nov) and December (Dec)), between the years 2001 and 2006, in the Upper Tapajos and Curua-Una River basins.

The minimum and maximum monthly $\mathrm{K} \downarrow$ values observed were $496.7 \mathrm{~W} \cdot \mathrm{m}^{-2}$ (February 2004) and $963.9 \mathrm{~W} \cdot \mathrm{m}^{-2}$ (August 2001), denoting an absolute difference of $467.2 \mathrm{~W} \cdot \mathrm{m}^{-2}$ (Figure 3). On average for the whole study period, the monthly $\mathrm{K} \downarrow$ was $716.3 \mathrm{~W} \cdot \mathrm{m}^{-2}$. The monthly average $\mathrm{K} \downarrow$ varied between 620.7 and $849.0 \mathrm{~W} \cdot \mathrm{m}^{-2}$. February presented the lowest values of $\mathrm{K} \downarrow$ while August presented the highest ones. This can be clearly seen on the maps in Figure 2. In February, especially in the southern and northern parts, most values are $\leqslant 600 \mathrm{~W} \cdot \mathrm{m}^{-2}$, while in August, practically in the whole area, are observed values $\geqslant 850 \mathrm{~W} \cdot \mathrm{m}^{-2}$. Rocha et al. [68], in a micrometeorological study in eastern Amazonia during 2000 and 2001, observed maximum values of $\mathrm{K} \downarrow$ in September and minimum values at the beginning of the wet season. The monthly average $\mathrm{K} \downarrow$ in the wet season was $663.2 \mathrm{~W} \cdot \mathrm{m}^{-2}$ while in the dry season it was $769.4 \mathrm{~W} \cdot \mathrm{m}^{-2}$, which means an increase in $\mathrm{K} \downarrow$ during the dry season of $\sim 16 \%$. The annual average $\mathrm{K} \downarrow$ values ranged from $672.2 \mathrm{~W} \cdot \mathrm{m}^{-2}(2003)$ to $758.6 \mathrm{~W} \cdot \mathrm{m}^{-2}(2001)$, which corresponds to a variation of $\sim 13 \%$. In 2003, the year with lowest incidence of solar radiation, the monthly $\mathrm{K} \downarrow$ varied from $498.3 \mathrm{~W} \cdot \mathrm{m}^{-2}$ (May) to $837.3 \mathrm{~W} \cdot \mathrm{m}^{-2}$ (August), and in 2001 ranged between 
$543.0 \mathrm{~W} \cdot \mathrm{m}^{-2}$ (January) and $963.9 \mathrm{~W} \cdot \mathrm{m}^{-2}$ (August). In 2005, the Amazon basin have experienced one of the most intense drought episodes of the last 100 years [69]. In this year, the average of solar radiation reaching the surface was $734.4 \mathrm{~W} \cdot \mathrm{m}^{-2}$, which corresponds to a value $\sim 3 \%$ than the average for the whole period $\left(716.3 \mathrm{~W} \cdot \mathrm{m}^{-2}\right)$. This increase occurred as expected and is most likely related to the reduction of cloudiness over Amazonia in this year especially during the wet season. During the dry season, the greenhouse gases and smoke aerosols from a large number of fire burning events that occurred in this year [70] may have contributed more than usual to absorb or scatter the solar radiation. This is probably the reason why 2005 did not present the higher value of incoming shortwave radiation considering the six years analyzed.

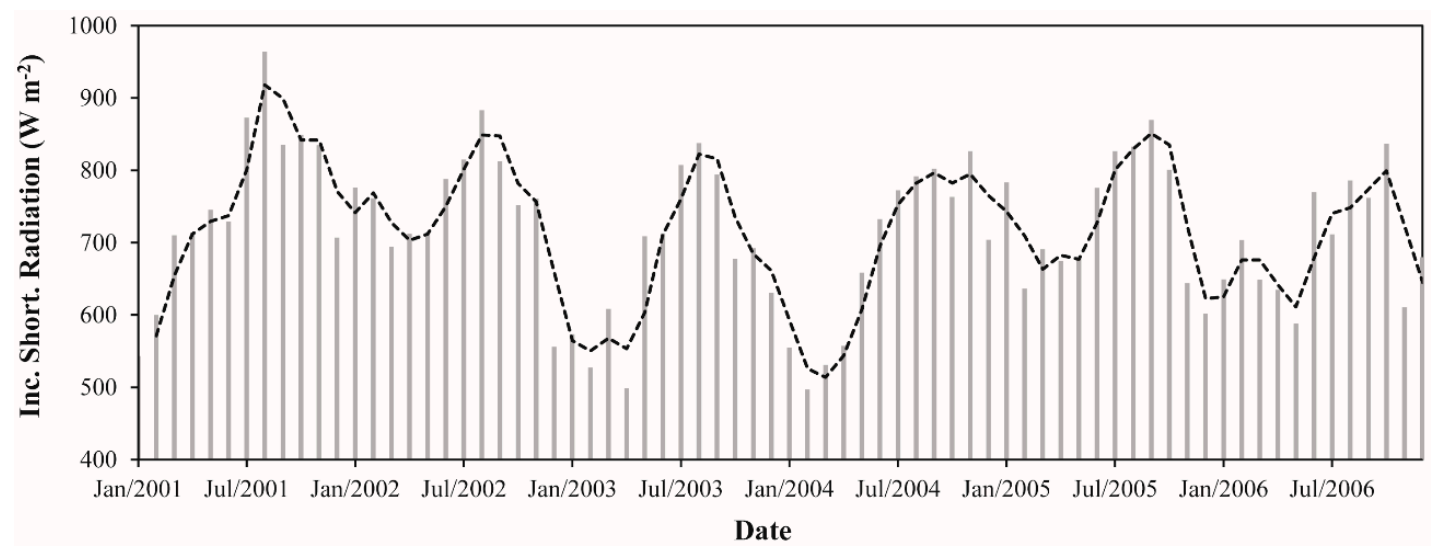

Figure 3. Monthly incoming shortwave radiation between January 2001 and December 2006 in the Upper Tapajos and Curua-Una River basins. The dashed black line represents the moving average of time series (period $=2$ ).

\subsubsection{Albedo}

The images with the highest values of albedo corresponded to the months from October to May (Figure 4). These images presented values generally $\geqslant 0.18$ while the maps of June, July, August and September showed values typically $\leqslant 0.16$. As can be noted, there is a decrease in albedo in the early dry season. Local-scale studies developed in Amazonia have been shown the highest albedo values generally occurring at the same time as the driest soil moisture conditions (dry season) [14,71]. Although the results here are different, we justify this behavior by the high increase of solar radiation reaching the earth surface in this region at this time of the year. That is, the decrease in surface moisture, which can causes a lower absorption of solar radiation (and consequently a higher albedo), is cancelled by a large increase in incoming shortwave radiation, resulting in a reduction of albedo. It is interesting to note that in most images, the highest values of albedo are located in the eastern part of the study area, more precisely in the Curua-Una River basin. It can be clearly seen between June and December. This area is situated within the so-called arc of deforestation, which is under higher pressure from human settlement and where the deforestation actually occurs [72]. We can also observe in the black dashed circle over the image of July the spatial pattern of deforestation in the Amazon, known as the fish spine [73]. In this regard, it is possible to verify the difference of albedo values between logged and forested areas, with the later presenting lower values. Because they are darker, forests absorb more solar radiation than short vegetation, having thus a smaller albedo [74-77]. 

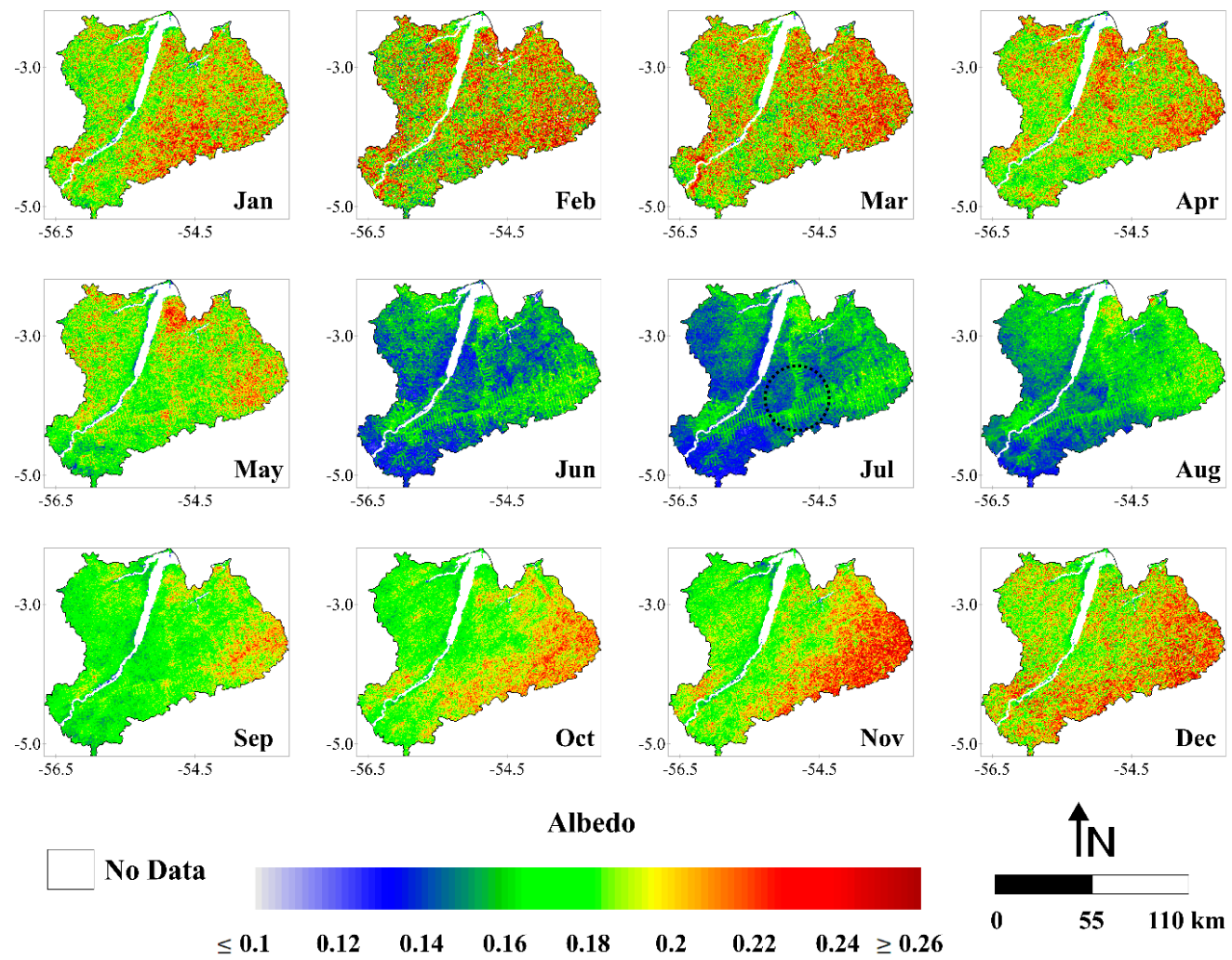

Figure 4. Monthly averages of albedo (months of January (Jan), February (Feb), March (Mar), April (Apr), May (May), June (Jun), July (Jul), August (Aug), September (Sep), October (Oct), November (Nov) and December (Dec)), between the years 2001 and 2006, in the Upper Tapajos and Curua-Una River basins.

The monthly albedo values ranged from 0.134 to 0.213 , a relative difference of $\sim 59 \%$. These values were observed in June 2006 and February 2003, respectively (Figure 5). Considering the average between 2001 and 2006, the monthly albedo corresponded to 0.182 . Regarding the monthly average, July and February were the months with lowest (0.152) and highest $(0.20)$ albedo values, respectively. Also, the monthly average albedo is $\sim 5 \%$ lower in the dry season compared with the wet season. For the dry season, the monthly average albedo was 0.177 while in the wet season was 0.187 . The annual average albedo values varied between 0.178 (2005) and 0.185 (2002 and 2003), constituting an absolute difference of $0.007(\sim 4 \%)$. This result evidence a small interannual variation of albedo in the eastern flank of Amazonia.

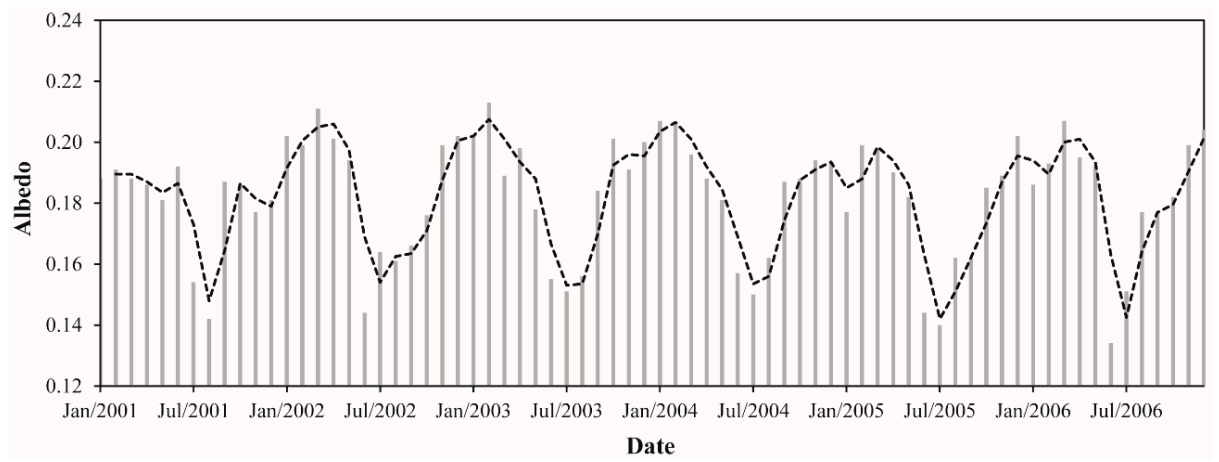

Figure 5. Monthly albedo between January 2001 and December 2006 in the Upper Tapajos and Curua-Una River basins. The dashed black line represents the moving average of time series (period $=2)$. 


\subsubsection{Incoming Longwave Radiation}

In Figure 6, we can note that the highest amounts of $\mathrm{\downarrow} \downarrow$ reaching the surface during the year are generally located in the western side of the study area (Upper Tapajos River basin). This is because this basin contains a larger forest area than the Curua-Una River basin. Several studies show that $L \downarrow$ in forest is higher than the pasture or agricultural areas [75,78]. The lowest values of $L \downarrow$ were observed between January and June while the hightest ones were observed from July to December. During the wet season (January to June) the values were generally $\leqslant 360 \mathrm{~W} \cdot \mathrm{m}^{-2}$. For the dry season (July to December) observed values were mostly $\geqslant 370 \mathrm{~W} \cdot \mathrm{m}^{-2}$. As we described in Section $2.5, \mathrm{~L} \downarrow$ was estimated by the Stefan-Boltzmann law, therefore being greatly influenced by the air temperature. According Rocha et al. [68], the dry season air temperature is $\sim 1-3{ }^{\circ} \mathrm{C}$ higher than the wet season for the region. Analyzing the air temperature data from GLDAS we found that air temperature in the study area was $\sim 5^{\circ} \mathrm{C}$ higher in the dry season in comparison with the wet season. Therefore, the increase of $\mathrm{L} \downarrow$ in the dry season occurred as expected.
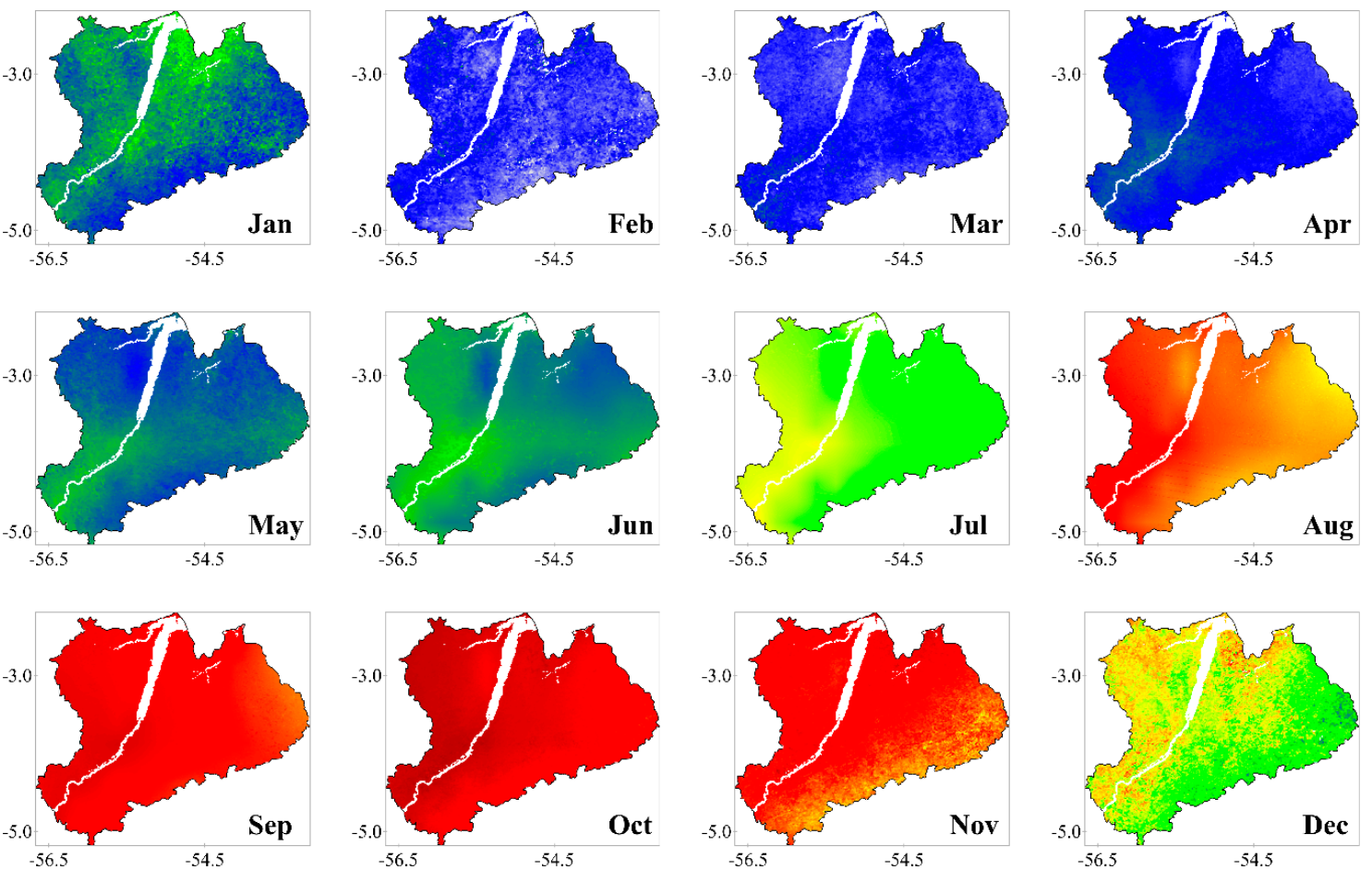

Incoming Longwave Radiation ( $\mathrm{W} \mathrm{m}^{-2}$ )

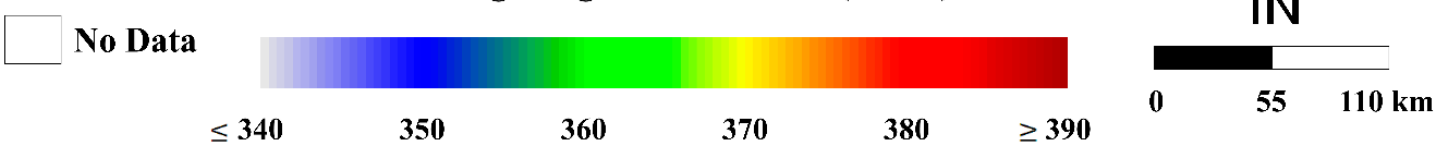

Figure 6. Monthly averages of incoming longwave radiation $\left(\mathrm{W} \cdot \mathrm{m}^{-2}\right)$ (months of January (Jan), February (Feb), March (Mar), April (Apr), May (May), June (Jun), July (Jul), August (Aug), September (Sep), October (Oct), November (Nov) and December (Dec)), between the years 2001 and 2006, in the Upper Tapajos and Curua-Una River basins.

The monthly $\mathrm{L} \downarrow$ ranged from $341.2 \mathrm{~W} \cdot \mathrm{m}^{-2}$ (February 2004) to $390.1 \mathrm{~W} \cdot \mathrm{m}^{-2}$ (October 2006), representing an absolute difference of $48.9 \mathrm{~W} \cdot \mathrm{m}^{-2}(\sim 14 \%)$ (Figure 7). The average monthly L $\downarrow$ for the whole period was $363.9 \mathrm{~W} \cdot \mathrm{m}^{-2}$. The lowest and highest values of monthly average $\mathrm{L} \downarrow$ happened in the beginning of the dry season (February) and late wet season (October) and corresponded to 347.6 and $384.7 \mathrm{~W} \cdot \mathrm{m}^{-2}$, respectively. The monthly average $\mathrm{L} \downarrow$ in in the wet season was $352.0 \mathrm{~W} \cdot \mathrm{m}^{-2}$ while in the dry season was $375.8 \mathrm{~W} \cdot \mathrm{m}^{-2}$. This result shows an increase in $\mathrm{L} \downarrow$ during the dry 
season of $\sim 7 \%$. The annual average $\mathrm{L} \downarrow$ values varied between 360.5 and $365.5 \mathrm{~W} \cdot \mathrm{m}^{-2}$, revealing a relative difference of only 1\%. The years of 2004 and 2003 presented the lowest and highest values of $\mathrm{L} \downarrow$, respectively.

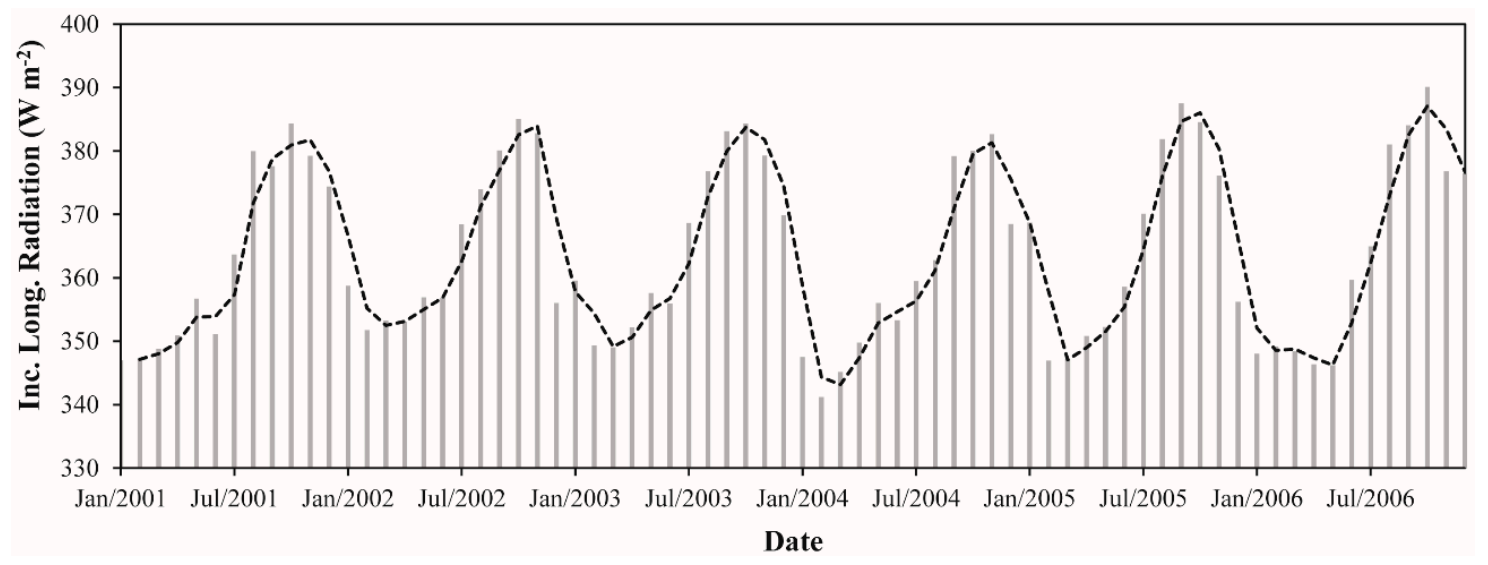

Figure 7. Monthly incoming longwave radiation between January 2001 and December 2006 in the Upper Tapajos and Curua-Una River basins. The dashed black line represents the moving average of time series (period $=2$ ).

\subsubsection{Outgoing Longwave Radiation}

The spatial pattern of $\mathrm{L} \uparrow$ reveals that the eastern portion of the study area has the highest emission of longwave radiation from the surface (Figure 8). As we discussed in Section 3.1.2, this region is strongly affected by deforestation. The conversion from forest to pasture or agricultural areas increases the surface temperature and alters the emissivity, resulting in an increase in L $\uparrow[78,79]$. The fish spine pattern is clearly observed in the images from July to December (black dashed circle over the image of October). The images with the highest values of $\mathrm{L} \uparrow$ corresponded to the months from July to December (dry season), following the pattern observed for $L \downarrow$ in Section 3.1.3. These images presented values generally $\geqslant 450 \mathrm{~W} \cdot \mathrm{m}^{-2}$ while the images of wet season (January to June) showed values generally $\leqslant 430 \mathrm{~W} \cdot \mathrm{m}^{-2}$. The estimation of $\mathrm{L} \uparrow$, similarly of $\mathrm{L} \downarrow$, was obtained through Stefan-Boltzmann law (described in Section 2.5). The primary difference in the estimation relies on the use of surface temperature instead of the atmospheric temperature. The MODIS surface temperature in the study area increased in the dry season about $2.4^{\circ} \mathrm{C}$ relative to the wet season, justifying the increment in $\mathrm{L} \uparrow$ during this time of the year.

The monthly $\mathrm{L} \uparrow$ ranged between 412.5 and $449.2 \mathrm{~W} \cdot \mathrm{m}^{-2}$, representing an absolute difference of $36.7 \mathrm{~W} \cdot \mathrm{m}^{-2}(\sim 9 \%)$ (Figure 9). These values were observed in February 2004 and October 2006, respectively. It is important to note that, as expected, the minimum and maximum values of $\mathrm{\downarrow} \downarrow$ were also found in February 2004 and October 2006, respectively. Considering the average during whole study period, we observed a monthly $\mathrm{L} \uparrow$ of $431.7 \mathrm{~W} \cdot \mathrm{m}^{-2}$. In terms of the monthly average, February and October showed the lowest $\left(418.6 \mathrm{~W} \cdot \mathrm{m}^{-2}\right)$ and highest values $\left(444.0 \mathrm{~W} \cdot \mathrm{m}^{-2}\right)$, respectively. A monthly average $\mathrm{L} \uparrow \sim 4 \%$ higher in the dry season in comparison with the wet season was also observed. For the wet season, the monthly average $\mathrm{L} \uparrow$ was $424.0 \mathrm{~W} \cdot \mathrm{m}^{-2}$ while in the dry season was $439.3 \mathrm{~W} \cdot \mathrm{m}^{-2}$. The annual average $\mathrm{L} \uparrow$ values varied between $429.9 \mathrm{~W} \cdot \mathrm{m}^{-2}(2001)$ and $433.8 \mathrm{~W} \cdot \mathrm{m}^{-2}$ (2005). It constitutes a variation of $\sim 1 \%$, the same verified for $L \downarrow$ in the Section 3.1.3. These results demonstrate a very small interannual fluctuation in the longwave radiation components over the Upper Tapajos and Curua-Una River basins. 

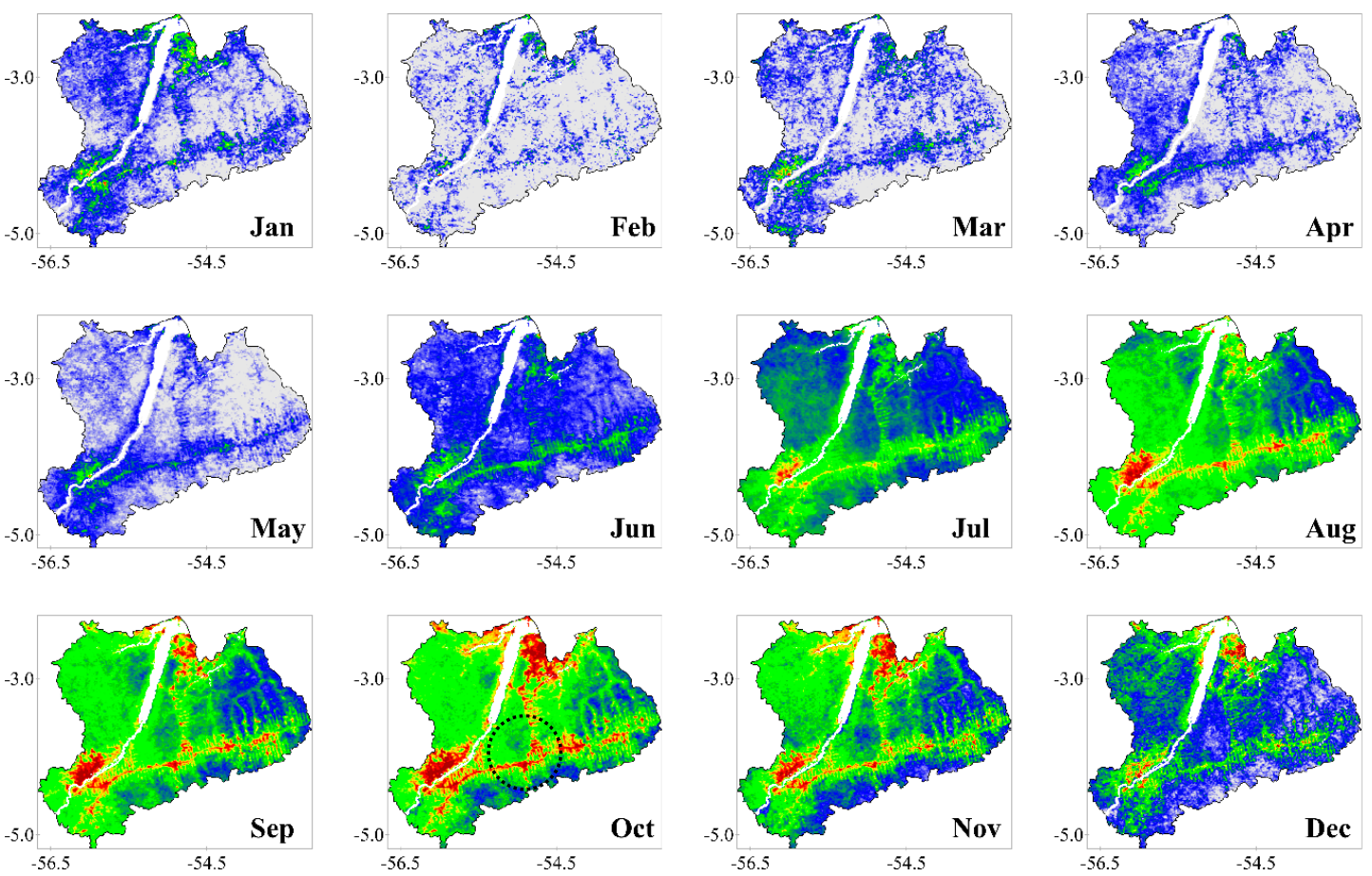

Outgoing Longwave Radiation (W m $\left.{ }^{-2}\right)$

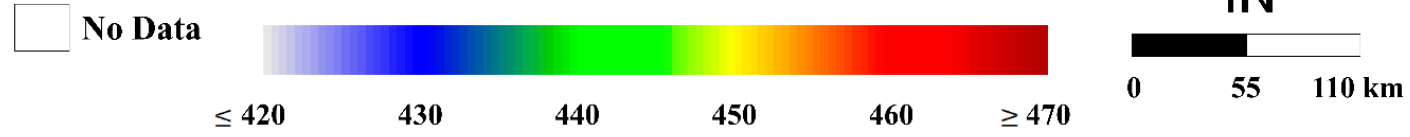

Figure 8. Monthly averages of outgoing longwave radiation $\left(\mathrm{W} \cdot \mathrm{m}^{-2}\right)$ (months of January (Jan), February (Feb), March (Mar), April (Apr), May (May), June (Jun), July (Jul), August (Aug), September (Sep), October (Oct), November (Nov) and December (Dec)), between the years 2001 and 2006, in the Upper Tapajos and Curua-Una River basins.

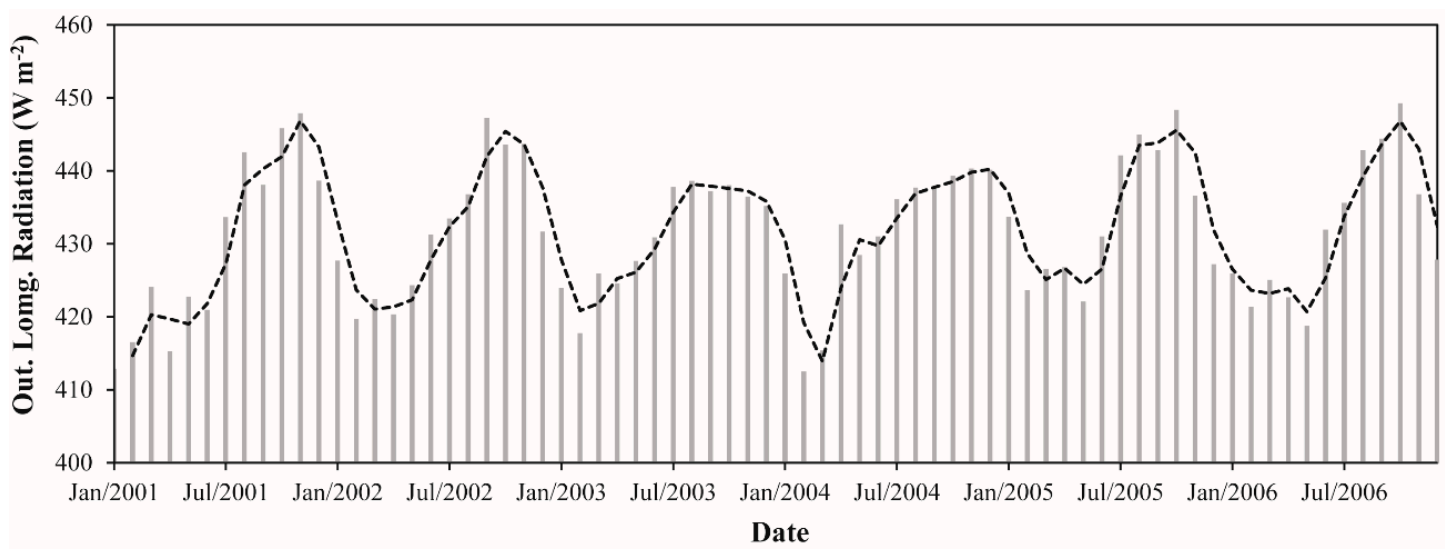

Figure 9. Monthly outgoing longwave radiation between January 2001 and December 2006 in the Upper Tapajos and Curua-Una River basins. The dashed black line represents the moving average of time series (period $=2$ ).

\subsubsection{Net Radiation}

The highest values of Rn are shown to be situated in the western part of the study area (Figure 10). As discussed before, this area is better preserved in terms of deforestation. Rn over forest areas is higher than in pasture areas, due to differences in the outgoing solar radiation (albedo) and in the longwave 
radiation balance $[75,80]$. In the images of June, July, August and September is possible to verify the fish spine pattern (black dashed circles), also clearly observed in the albedo images (Section 3.1.2) and $\mathrm{L} \uparrow$ (Section 3.1.4). This data shows that logged areas, mostly of which were converted posteriorly to pasture, present higher albedo and $\mathrm{L} \uparrow$ and lower $\mathrm{Rn}$, compared to forested areas. This result is in agreement with various observational studies in the Amazon [3,65,81,82].
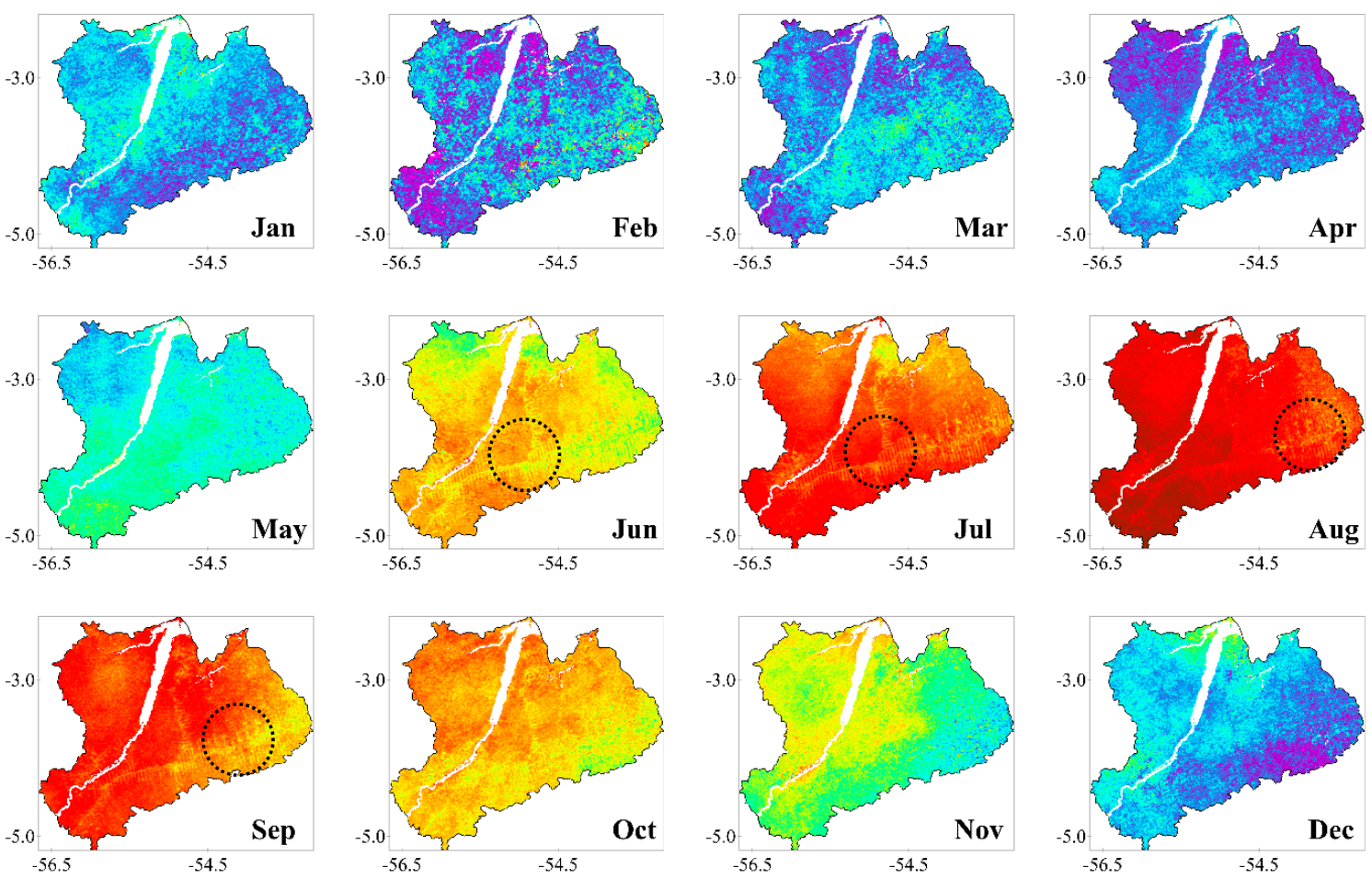

Net Radiation (W m $\left.{ }^{-2}\right)$

No Data
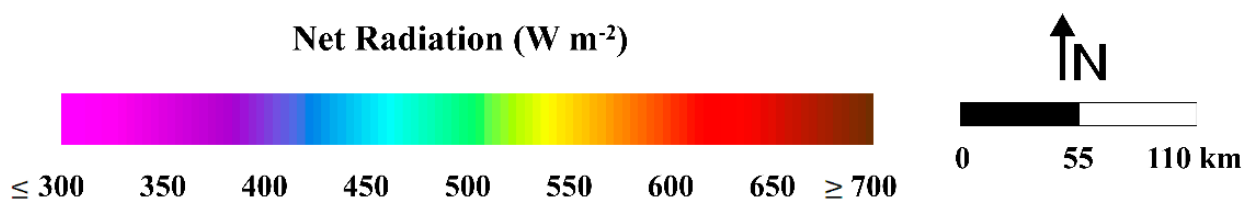

Figure 10. Monthly averages of net radiation $\left(\mathrm{W} \cdot \mathrm{m}^{-2}\right.$ ) (months of January (Jan), February (Feb), March (Mar), April (Apr), May (May), June (Jun), July (Jul), August (Aug), September (Sep), October (Oct), November (Nov) and December (Dec)), between the years 2001 and 2006, in the Upper Tapajos and Curua-Una River basins.

Rn values are higher from June to November compared to the December to April period. This is the same pattern observed for the incoming shortwave radiation (described in Section 3.1.1). It occurs due the strong and linear correlation between solar radiation and net radiation in Amazonia, noticed by several previous studies [12,75]. As discussed in Section 3.1.1, the dry season has the highest amounts of solar radiation reaching the surface in the Amazon region because of the reduction in cloud cover. This is predicted even considering the large presence of smoke aerosols from fire burning events during this time of the year, which may cause reductions of total solar irradiance [64-67]. Therefore, with the reduction in cloud cover and consequent increase in $K \downarrow$, Rn increases during the driest period of the year as expected, demonstrating the effectiveness of our methodology to capture the seasonal variation of $\mathrm{Rn}$ in the study area.

The monthly Rn varied between 308.8 (February 2004) and $750.7 \mathrm{~W} \cdot \mathrm{m}^{-2}$ (August 2001). It denotes an absolute difference of $441.9 \mathrm{~W} \cdot \mathrm{m}^{-2}(\sim 143 \%)$ (Figure 11). The monthly averaged Rn over the period was $505.5 \mathrm{~W} \cdot \mathrm{m}^{-2}$. The monthly average ranged from 411.7 to $635.6 \mathrm{~W} \cdot \mathrm{m}^{-2}$, with February presenting the lowest value and August presenting the highest one. We can note that in February most values are 
$\leqslant 450 \mathrm{~W} \cdot \mathrm{m}^{-2}$, while in August the values are generally $\geqslant 600 \mathrm{~W} \cdot \mathrm{m}^{-2}$ (Figure 10). Hutyra et al. [43] in a micrometeorological study developed in this region also found minimum and maximum values of $\mathrm{Rn}$ at the beginning of wet and dry season, respectively. The monthly average $\mathrm{Rn}$ in the wet and dry season was 453.8 and $556.7 \mathrm{~W} \cdot \mathrm{m}^{-2}$, respectively, showing that $\mathrm{Rn}$ increased $\sim 23 \%$ in the dry season. This result is in agreement with the study of Costa et al. [83], which observed for the same region an increase of about $18 \%$ in Rn during the dry season using surface data. The annual average Rn values varied from 470.0 to $543.2 \mathrm{~W} \cdot \mathrm{m}^{-2}$, which corresponds to a variation of $\sim 16 \%$. This result shows a large interannual variation of $\mathrm{Rn}$ in the study area. It should be noted that, between all the parameters analyzed, Rn presented the highest interannual variation $(\mathrm{K} \downarrow=13 \%$, albedo $=\sim 4 \%, \mathrm{~L} \downarrow$ and $\mathrm{L} \uparrow=\sim 1 \%)$. The years with the lowest and highest amounts of energy available at the surface were 2003 and 2001, respectively. These years coincide exactly with the years with smallest and largest amounts of solar radiation reaching the surface in the region, as discussed in Section 3.1.1. In 2005, when a severe drought occurred over the Amazon region [69,70], we observed an average Rn value $\sim 3 \%$ higher than the annual average for the whole period. This increment is related to the increase of $\mathrm{K} \downarrow$ observed in this year, which was also of about $\sim 3 \%$ (Section 3.1.1). As discussed previously, it probably occurred due to the reduction of cloud cover especially during the wet season in this year. We highlight that 2005 was not the year with highest value of $\mathrm{Rn}$ in the temporal series probably because of the large amounts of greenhouse gases and aerosols from fire burning events were released to the atmosphere in the dry season of this year, contributing to either the absorption or scattering of the solar radiation.

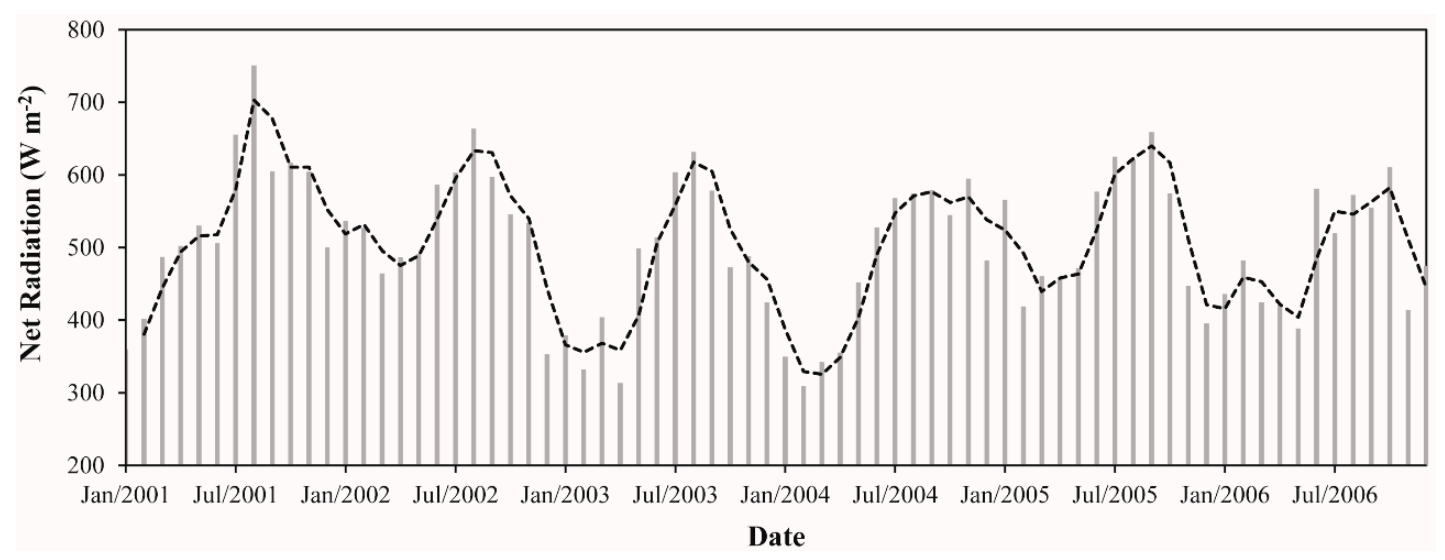

Figure 11. Monthly net radiation between January 2001 and December 2006 in the Upper Tapajos and Curua-Una River basins. The dashed black line represents the moving average of time series (period $=2)$.

\subsection{Temporal Dynamics of Net Radiation for Different Land Cover Types}

Figure 12 shows the trajectories of instantaneous net radiation for five different land cover types during the period from 2001 to 2006. The land cover types analyzed corresponded to agriculture (AG), bare soil (BS), primary tropical forest (PF), pasture (PA) and secondary succession forest (SF). Overall, most of the land cover types had a similar monthly variation, with a maximum in the dry season and a minimum in the wet season. It follows the pattern observed for the whole study area, as discussed in Section 3.1.5. Considering the average for the entire study period, the highest ecosystem Rn value was for BS $\left(534.0 \mathrm{~W} \cdot \mathrm{m}^{-2}\right)$, while AG presented the lowest one $\left(495.6 \mathrm{~W} \cdot \mathrm{m}^{-2}\right)$. We observed that the highest and lowest Rn values found for BS and AG are related, respectively, to the lower and higher albedo observed in these ecosystems. The monthly Rn varied from 369.7 (March 2005) to $657.5 \mathrm{~W} \cdot \mathrm{m}^{-2}$ (October 2001) and from 211.2 (January 2004) to $722.9 \mathrm{~W} \cdot \mathrm{m}^{-2}$ (October 2001) for BS and AG, respectively. The PA presented a temporal average $\mathrm{Rn}$ of $496.7 \mathrm{~W} \cdot \mathrm{m}^{-2}$, very similar to that found in AG. Wright et al. [84] and Galvao and Fish [85] observed for pasture sites in the Brazilian states of Amazonas and Rondonia, respectively, at 11:00 a.m., values about $500 \mathrm{~W} \cdot \mathrm{m}^{-2}$, which are close to 
those we found in our study. The monthly average Rn in the wet and dry season was 444.8 and 540.7 $\mathrm{W} \cdot \mathrm{m}^{-2}$, respectively.

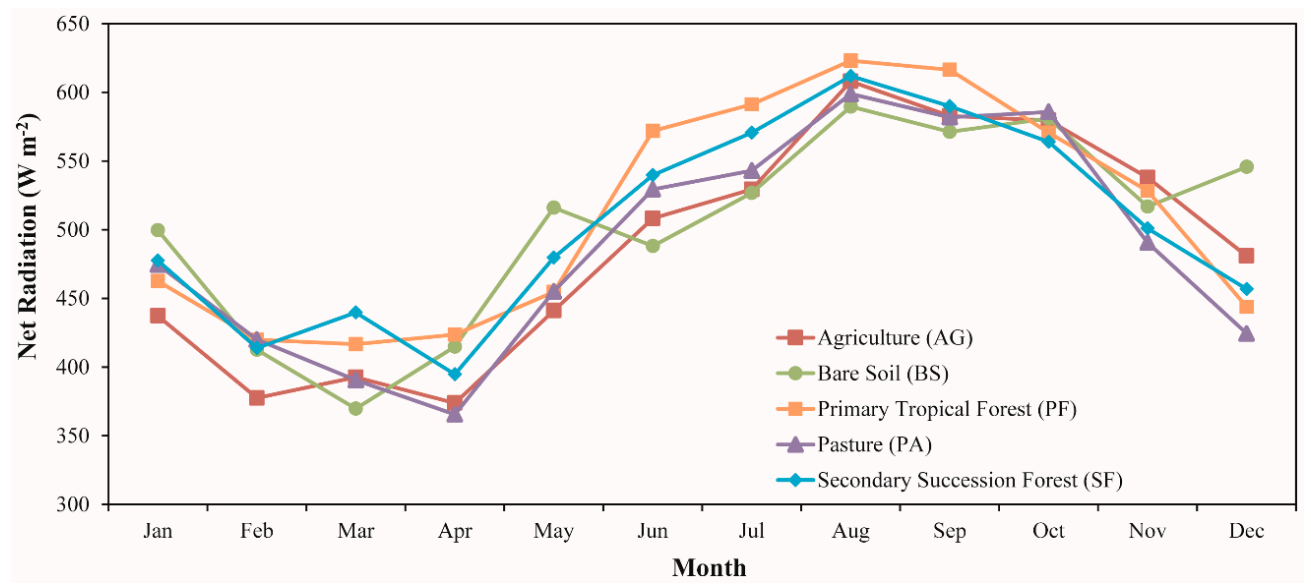

Figure 12. Seasonal patterns of net radiation under agriculture (AG), bare soil (BS), primary tropical forest (PF), pasture and secondary succession forest (SF). The monthly average was calculated based on the period between 2001 and 2006.

In the PF, we observed an average value of $511.6 \mathrm{~W} \cdot \mathrm{m}^{-2}$. Micrometeorological studies developed by Von Randow et al. [71] and Aguiar [86] observed values of 450 and $530 \mathrm{~W} \cdot \mathrm{m}^{-2}$ in an LBA forest site in the southwestern part of Amazonia (average for 11:00 a.m. local time). Rn varied between 459.4 and $562.2 \mathrm{~W} \cdot \mathrm{m}^{-2}$ in the wet and dry season, respectively, meaning an increase during the dry season of about $22 \%$. It is important to notice that Rn in PF was approximately $3 \%$ higher than the PA and AG, illustrating that deforestation influences the availability of energy at the surface, leading, among others, to consequences for evapotranspiration [71,87-89]. With respect to SF, an average value for the study period of $507.5 \mathrm{~W} \cdot \mathrm{m}^{-2}$ was observed ranging between $293.6 \mathrm{~W} \cdot \mathrm{m}^{-2}($ March 2004$)$ and $742.3 \mathrm{~W} \cdot \mathrm{m}^{-2}$ (August 2001). The Rn during wet and dry season was about 460.8 and $549.0 \mathrm{~W} \cdot \mathrm{m}^{-2}$, respectively, showing a variation of $\sim 19 \%$. It is not possible to guarantee what is exactly the age of the secondary forest plots analyzed, but it is interesting to note that the Rn is only $\sim 1 \%$ lower to that observed for the primary forest. It shows that with time, the secondary forest can recover its original state in terms of radiation fluxes, consequently reducing the impact of the deforestation on the climatology of Amazon region.

\subsection{Validation of Reanalysis Data}

The MRE in the incoming shortwave radiation was approximately $10 \%-11 \%$ of the field measurements (Table 1). The bias varied from 45.7 to $70.5 \mathrm{~W} \cdot \mathrm{m}^{-2}$, while the RMSE ranged from 72.7 to $86.5 \mathrm{~W} \cdot \mathrm{m}^{-2}$. Baik and Choi [62], comparing $\mathrm{K} \downarrow$ obtained from satellite images and ground data, observed biases and RMSE varying between -21.6 to $-112.6 \mathrm{~W} \cdot \mathrm{m}^{-2}$ and 107.1 to $202.4 \mathrm{~W} \cdot \mathrm{m}^{-2}$, respectively. The average $\mathrm{r}^{2}$ was 0.82 , oscillating between 0.78 and 0.86 in $\mathrm{K} 77$ and $\mathrm{K} 83$ sites respectively. In a study developed by Shi and Liang [31] to analyze $\mathrm{K} \downarrow$ acquired from four different reanalysis datasets, it was found $\mathrm{r}^{2}$ values varying between 0.42 and 0.47 . In respect to daily incoming shortwave radiation, considering the two sites, the MRE was about $17 \%$. The bias and RMSE values were of the order of 25.4 to $36.5 \mathrm{~W} \cdot \mathrm{m}^{-2}$, and 32.2 to $41.2 \mathrm{~W} \cdot \mathrm{m}^{-2}$, respectively. In a daily basis, Hou et al. [9], observed biases and RMSE ranging from 21 to $25 \mathrm{~W} \cdot \mathrm{m}^{-2}$ and 27 to $28 \mathrm{~W} \cdot \mathrm{m}^{-2}$, respectively. The average $\mathrm{r}^{2}$ value verified in our study was 0.76 while Hou et al. [9] observed a value of 0.98 . In general, considering the incoming shortwave radiation (both instantaneous and daily) it is important to note that the values tend to be overestimated in comparison of ground data. Also, it is verified that the results were more accurate for the pasture (K77) than the forest site (K83). 
Table 1. Mean observed and estimated values, bias, root mean square error (RMSE), correlation coefficient $\left(\mathrm{r}^{2}\right)(p<0.05)$ and mean relative error (MRE) $(\%)$ for incoming shortwave radiation, daily incoming shortwave radiation and air temperature.

\begin{tabular}{llccc}
\hline & & K67 & K83 & K77 \\
\hline & Mean Obs. & - & 637.1 & 667.6 \\
Incoming Shortwave Radiation $(\mathrm{K} \downarrow)\left(\mathrm{W} \cdot \mathrm{m}^{-2}\right)$ & Mean Est. & - & 707.6 & 713.3 \\
& bias & - & 70.5 & 45.7 \\
& RMSE & - & 86.5 & 72.7 \\
& $\mathrm{r}^{2}$ & - & 0.86 & 0.78 \\
& MRE (\%) & - & 11.1 & 9.9 \\
\hline & Mean Obs. & - & 189.5 & 200.9 \\
Daily Incoming Shortwave Radiation $(\mathrm{K} \downarrow$ 24h $)\left(\mathrm{W} \cdot \mathrm{m}^{-2}\right)$ & Mean Est. & - & 226.0 & 226.3 \\
& bias & - & 36.5 & 25.4 \\
& RMSE & - & 41.2 & 32.2 \\
& r & - & 0.81 & 0.71 \\
Air Temperature $\left(\mathrm{T}_{\mathrm{a}}\right)\left({ }^{2} \mathrm{C}\right)$ & MRE (\%) & - & 19.5 & 14.0 \\
\hline & Mean Obs. & 27.2 & 27.4 & 28.9 \\
& Mean Est. & 29.0 & 29.0 & 29.1 \\
& bias & 1.8 & 1.6 & 0.2 \\
& RMSE & 2.3 & 2.3 & 1.4 \\
\hline
\end{tabular}

The air temperature presented the more accurate results of all reanalysis data analyzed in this study. In average for the three sites, the MRE was 5\%, varying between $3.7 \%$ (K77) and $6.6 \%$ (K67). For K83 was observed an MRE of $6.1 \%$. In the same manner as verified for $K \downarrow$ and $K \downarrow_{24 h}$, were found a higher agreement between GLDAS and LBA data under the condition of pasture than forest. The average bias and RMSE corresponded to 1.2 and $2{ }^{\circ} \mathrm{C}$, respectively, and $\mathrm{r}^{2}$ was of 0.80 . As we can note, air temperature values from GLDAS were overestimated. Bisht et al. [8], using MODIS images to estimate air temperature, observed a bias, RMSE and $\mathrm{r}^{2}$ of $-2.1^{\circ} \mathrm{C}, 5^{\circ} \mathrm{C}$ and $0.62{ }^{\circ} \mathrm{C}$, respectively. Based on the results obtained, we highlight that our hypothesis to use reanalysis data as input in SEBAL model is valid and can serve as alternative to the use of ground data in regions where there is a lack of such information.

\subsection{Validation of Model Estimates}

The results presented here encompass all of the estimates using MODIS images between 2001 and 2006, except when was NoData value (cloud mask) in the satellite dataset or error in ground observations. The albedo presented the highest MRE values between all the components of net radiation (Table 2). In average for the K83 and K77 sites, the MRE corresponded to $\sim 32 \%$. The MRE in K83 was $43.4 \%$ while in K77 was $20.1 \%$. There was an overestimation of 0.044 and 0.028 for the forest and pasture sites, respectively. In average, the RMSE was of 0.047 and $\mathrm{r}^{2}$ was of 0.16 . These results reveal a certain ineffectiveness of Liang's approach (described in Section 2.5) to retrieve the albedo through MOD09 products in the Amazon region. In a study validating the MCD43B3 product with observational data, Hou et al. [9] verified that albedo values were underestimated with a bias, RMSE and $\mathrm{r}^{2}$, in average, of $-0.024,0.029$ and 0.32 , respectively. Using different remote sensing datasets in Tibetan Plateau, Shi and Liang [31] observed RMSE and $r^{2}$ values of the order of 0.06 and 0.07 , and 0.04 and 0.10 , respectively.

Concerning the longwave components of the surface radiation budget, we found an MRE, in average, of $\sim 16 \%$ for the portion that is emitted from the atmosphere to the surface and $\sim 9 \%$ for portion that is emited from the surface to the atmosphere. Bisht and Bras [90] analyzing the accuracy of $\mathrm{L} \downarrow$ and $\mathrm{L} \uparrow$ estimated also from MODIS images found errors between $\sim 4 \%$ and $\sim 8 \%$ and $\sim 9 \%$ and $\sim 12 \%$, respectively. For both components were observed an underestimation, in average, of -68.6 and $-41.5 \mathrm{~W} \cdot \mathrm{m}^{-2}$, for incoming and outgoing longwave radiation, respectively. The RMSE ranged from 
66.6 to $73.9 \mathrm{~W} \cdot \mathrm{m}^{-2}$ for the incoming portion and from 37.1 to $47.9 \mathrm{~W} \cdot \mathrm{m}^{-2}$ for the outgoing portion. The correlation coefficient, in average, was about 0.06 and 0.47 for $\mathrm{L} \downarrow$ and $\mathrm{L} \uparrow$, respectively. Oliveira and Moraes [36] observed biases between -55.8 and $13.4 \mathrm{~W} \cdot \mathrm{m}^{-2}\left(-21.2 \mathrm{~W} \cdot \mathrm{m}^{-2}\right.$ in average), and -41.8 and $-15.3 \mathrm{~W} \cdot \mathrm{m}^{-2}\left(-28.6 \mathrm{~W} \cdot \mathrm{m}^{-2}\right.$ in average) for incoming and outgoing longwave radiation, respectively. In regard to RMSE, Bisht and Bras [90] verified values for $\mathrm{L} \downarrow$ between 28.2 and $37.6 \mathrm{~W} \cdot \mathrm{m}^{-2}$, and for $\mathrm{L} \uparrow$ ranging from 17.1 to $35.3 \mathrm{~W} \cdot \mathrm{m}^{-2}$. The $\mathrm{r}^{2}$ obtained by Shi and Liang [31] were about 0.12 and 0.02 for $\mathrm{L} \downarrow$ and $\mathrm{L} \uparrow$, respectively. We can observe, in general, that the results for the longwave components were better for the outgoing portion. This is in accordance other studies which point out that the longwave radiation emitted by atmosphere into the surface is one of the components of radiation budget more difficult to retrieve $[79,91]$. As described in Section 2.5, the SEBAL model uses the Stefan-Boltzmann law to obtain $\mathrm{L} \downarrow$, assuming that the atmospheric emissivity can be computed through an empirical formula based on atmospheric transmissivity, which is a function primarily of the altitude of the study area. We consider that this is a very simple assumption, and according to various authors [92,93] the accurate estimation of $\mathrm{L} \downarrow$ relies on information about greenhouse gas concentrations and profiles of moisture and air temperature. However, these kind of data are extremely costly to obtain and compile.

Table 2. Mean observed and estimated values, bias, root mean square error (RMSE), correlation coefficient $\left(\mathrm{r}^{2}\right)(p<0.05)$ and mean relative error (MRE) $(\%)$ for albedo, incoming and outgoing longwave radiation, net radiation and daily net radiation.

\begin{tabular}{|c|c|c|c|c|}
\hline & & K67 & K83 & K77 \\
\hline \multirow{6}{*}{ Albedo } & Mean Obs. & - & 0.110 & 0.169 \\
\hline & Mean Est. & - & 0.153 & 0.197 \\
\hline & bias & - & 0.044 & 0.028 \\
\hline & RMSE & - & 0.052 & 0.041 \\
\hline & $\mathrm{r}^{2}$ & - & 0.18 & 0.14 \\
\hline & MRE (\%) & - & 43.4 & 20.1 \\
\hline \multirow{6}{*}{ Incoming Longwave Radiation $(\mathrm{L} \downarrow)\left(\mathrm{W} \cdot \mathrm{m}^{-2}\right)$} & Mean Obs. & - & 436.8 & 441.0 \\
\hline & Mean Est. & - & 371.5 & 369.2 \\
\hline & bias & - & -65.3 & -71.8 \\
\hline & RMSE & - & 66.6 & 73.9 \\
\hline & $\mathrm{r}^{2}$ & - & 0.06 & 0.05 \\
\hline & MRE (\%) & - & 14.9 & 16.2 \\
\hline \multirow{6}{*}{ Outgoing Longwave Radiation $(\mathrm{L} \uparrow)\left(\mathrm{W} \cdot \mathrm{m}^{-2}\right)$} & Mean Obs. & - & 468.7 & 486.9 \\
\hline & Mean Est. & - & 432.3 & 440.4 \\
\hline & bias & - & -36.4 & -46.5 \\
\hline & RMSE & - & 37.1 & 47.9 \\
\hline & $\mathrm{r}^{2}$ & - & 0.34 & 0.59 \\
\hline & MRE (\%) & - & 7.8 & 9.5 \\
\hline \multirow{6}{*}{ Net Radiation $(\mathrm{Rn})\left(\mathrm{W} \cdot \mathrm{m}^{-2}\right)$} & Mean Obs. & 489.0 & 466.6 & 480.7 \\
\hline & Mean Est. & 525.6 & 521.6 & 511.2 \\
\hline & bias & 36.6 & 55.1 & 30.5 \\
\hline & RMSE & 68.2 & 88.8 & 71.6 \\
\hline & $\mathrm{r}^{2}$ & 0.64 & 0.78 & 0.35 \\
\hline & MRE (\%) & 12.5 & 16.4 & 13.1 \\
\hline \multirow{6}{*}{ Daily Net Radiation $\left(\mathrm{Rn}_{24 \mathrm{~h}}\right)\left(\mathrm{W} \cdot \mathrm{m}^{-2}\right)$} & Mean Obs. & 128.9 & 132.9 & 126.6 \\
\hline & Mean Est. & 115.9 & 127.4 & 113.6 \\
\hline & bias & -13.0 & -5.4 & -13.0 \\
\hline & RMSE & 18.7 & 19.7 & 24.8 \\
\hline & $\mathrm{r}^{2}$ & 0.57 & 0.31 & 0.06 \\
\hline & MRE (\%) & 11.3 & 12.1 & 15.9 \\
\hline
\end{tabular}

The MRE in instantaneous and daily net radiation were, in average for the three sites, of the order of $14 \%$ and $13 \%$, respectively. Other studies also using orbital images presented errors in Rn and $\mathrm{Rn}_{24 \mathrm{~h}}$ ranging between $\sim 13 \%$ and $\sim 24 \%$ [90] and $\sim 12 \%$ and $\sim 14 \%$ [9], respectively. The Rn tended to be overestimated, with biases varying between 30.5 and $55.1 \mathrm{~W} \cdot \mathrm{m}^{-2}$, while the $\mathrm{Rn}_{24 \mathrm{~h}}$ tended to be underestimated, with biases ranging from -5.4 and $-13.0 \mathrm{~W} \cdot \mathrm{m}^{-2}$. In average, the biases for $\mathrm{Rn}$ and $\mathrm{Rn}_{24 \mathrm{~h}}$ corresponded to 40.8 and $-10.5 \mathrm{~W} \cdot \mathrm{m}^{-2}$. Bisht et al. [8] verified biases of $59 \mathrm{~W} \cdot \mathrm{m}^{-2}(\mathrm{Rn})$ and 
$50 \mathrm{~W} \cdot \mathrm{m}^{-2}\left(\mathrm{Rn}_{24 \mathrm{~h}}\right)$. The RMSE was, in average, 76.2 and $21.1 \mathrm{~W} \cdot \mathrm{m}^{-2}$ for $\mathrm{Rn}$ and $\mathrm{Rn}_{24 \mathrm{~h}}$, respectively. The RMSE values were very close to those found by the studies of Bisht et al. [8] and Shi and Liang [31]. The first one obtained a RMSE for $\mathrm{Rn}$ of $\sim 74 \mathrm{~W} \cdot \mathrm{m}^{-2}$ while the second verified a RMSE for $\mathrm{Rn}_{24 \mathrm{~h}}$ of $\sim 24 \mathrm{~W} \cdot \mathrm{m}^{-2}$. The $\mathrm{r}^{2}$ varied from 0.35 to 0.78 for $\mathrm{Rn}$ and from 0.06 to 0.57 for $\mathrm{Rn}_{24 \mathrm{~h}}$ (as shown in Figures 13 and 14). For both $\mathrm{Rn}$ and $\mathrm{Rn}_{24 \mathrm{~h}}$, the lowest correlation values were verified at $\mathrm{K} 77$ site. In average, the $\mathrm{r}^{2}$ was about 0.60 and 0.31 for $\mathrm{Rn}$ and $\mathrm{Rn}_{24 \mathrm{~h}}$, respectively. Comparing with other studies also estimating this parameters through MODIS images, we observed $\mathrm{r}^{2}$ values of the order of $0.78(\mathrm{Rn})$ [94] and $0.57\left(\mathrm{Rn}_{24 \mathrm{~h}}\right)$ [30].
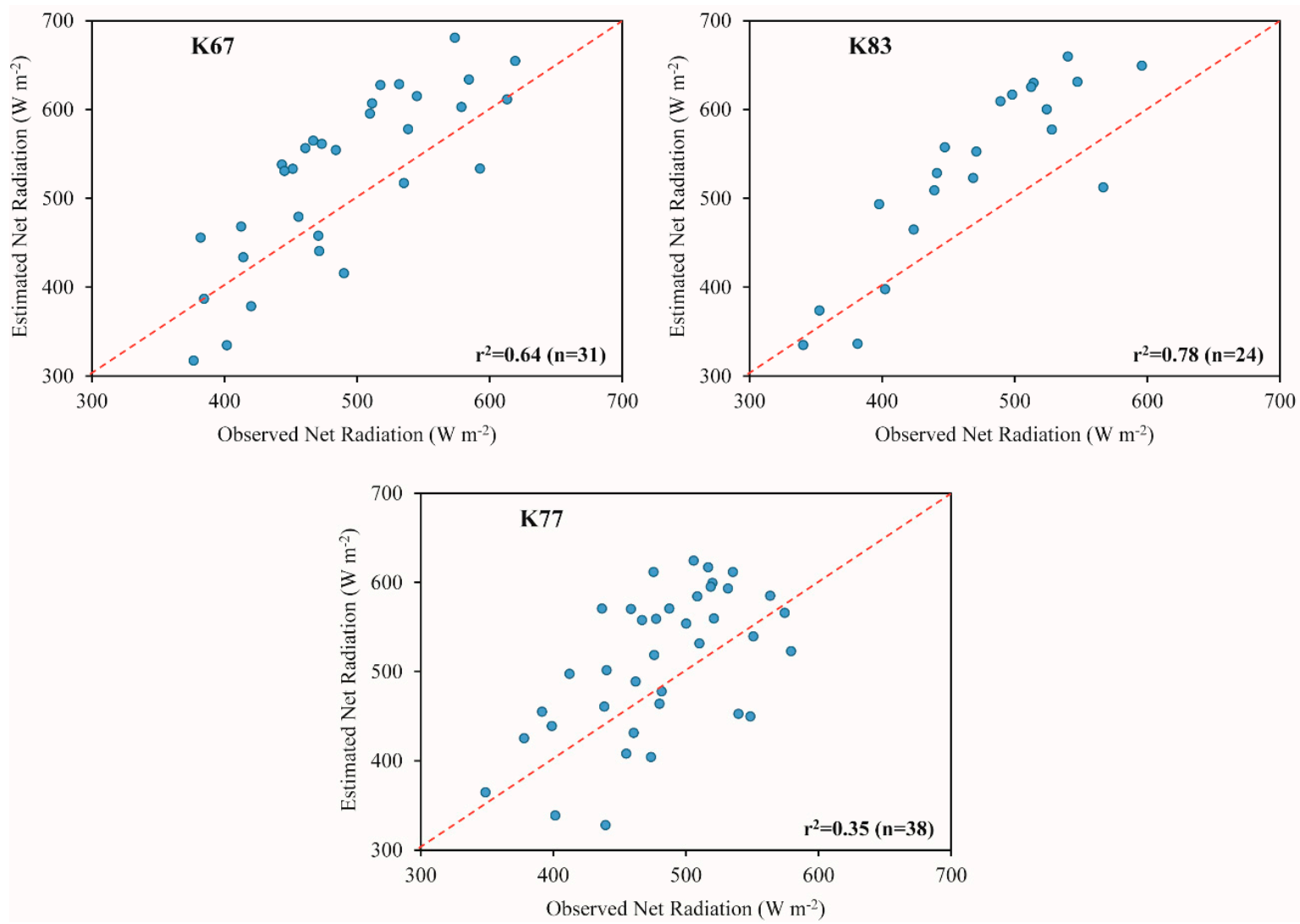

Figure 13. Comparison of observed and estimated net radiation at K67, K83 and K77 LBA sites. The number of correlative measurements is represented by " $n$ ".
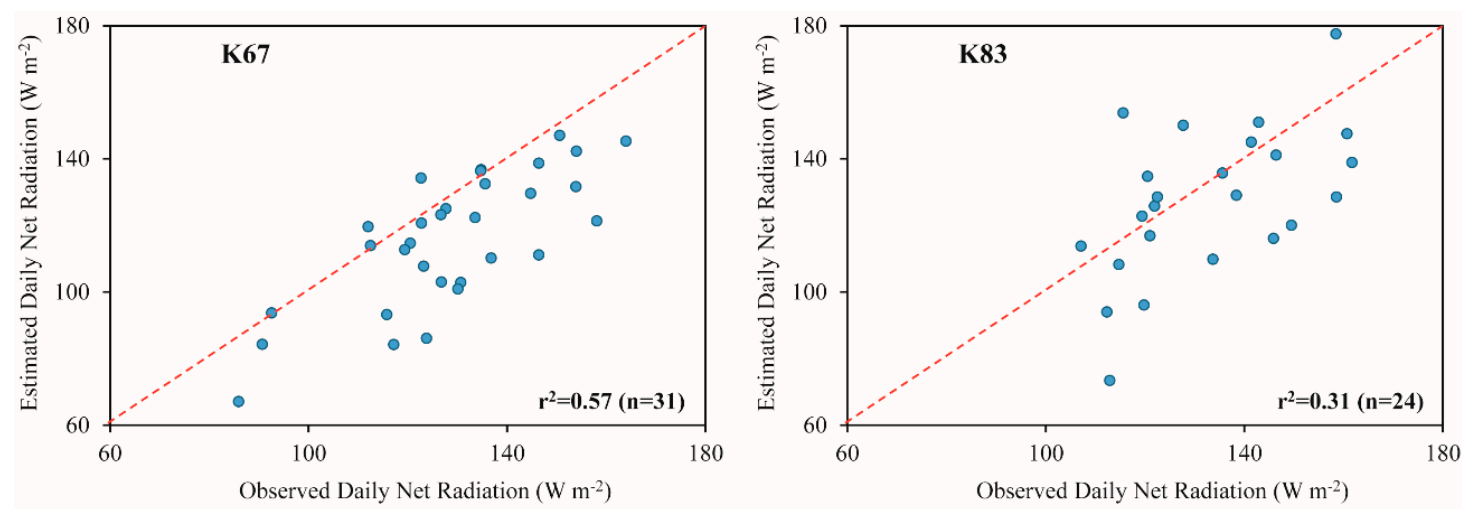

Figure 14. Cont. 


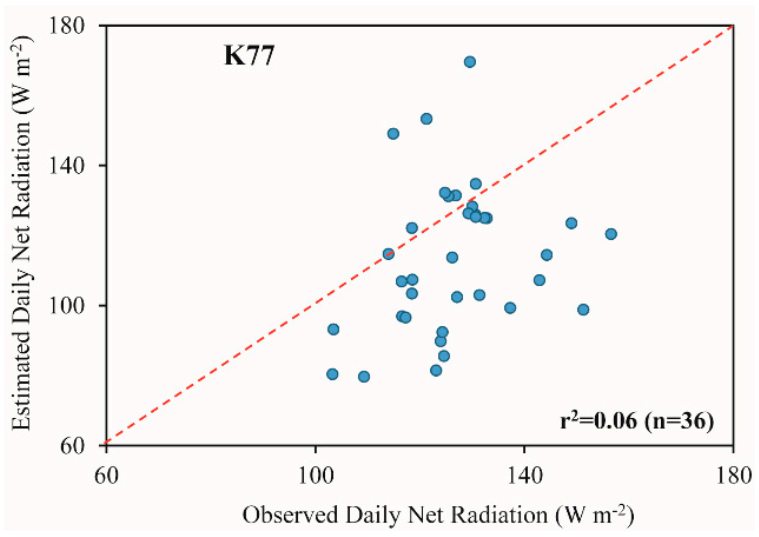

Figure 14. Comparison of observed and estimated daily net radiation at K67, K83 and K77 LBA sites. The number of correlative measurements is represented by " $n$ ".
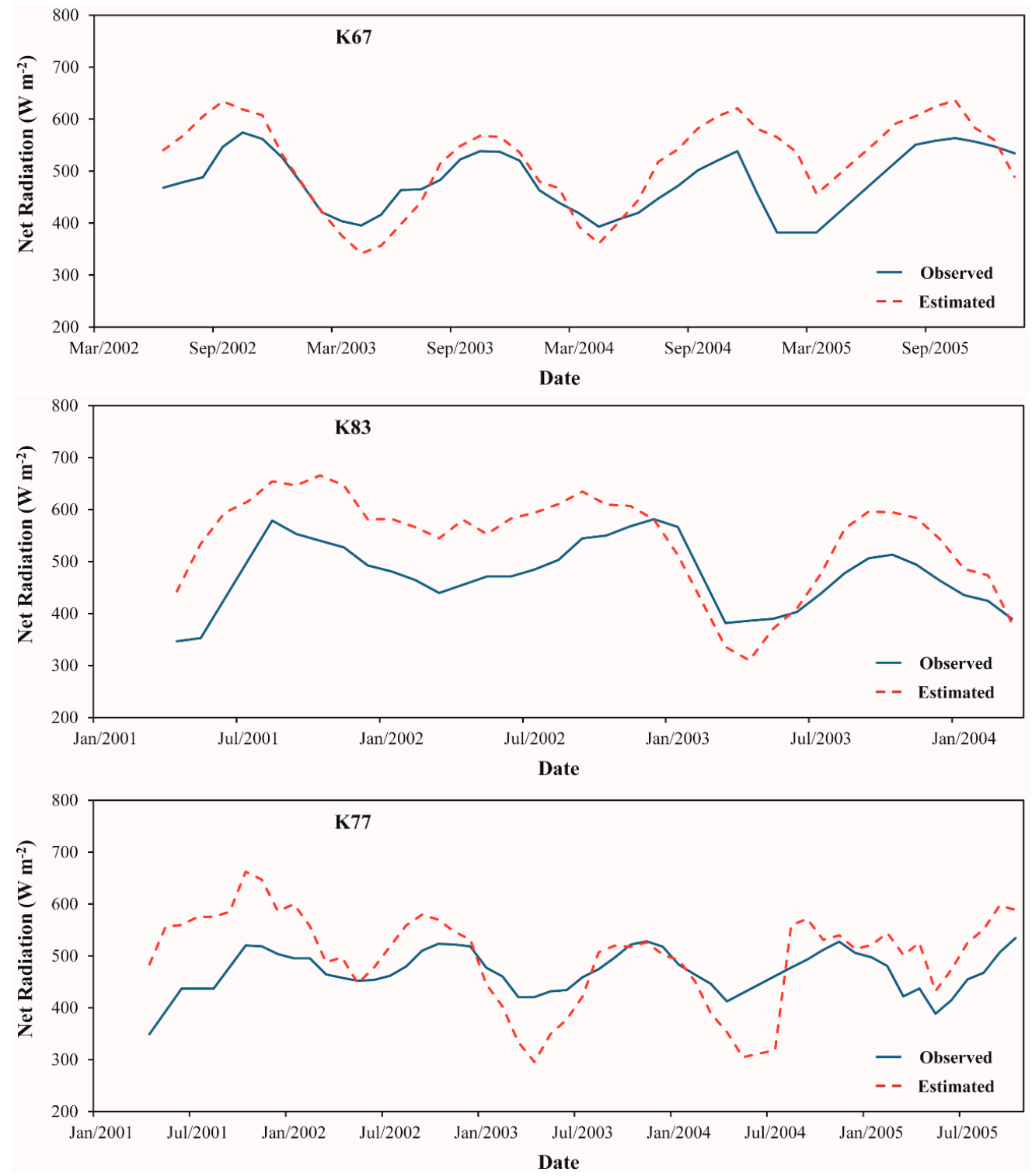

Figure 15. Moving average of the monthly cycle of net radiation estimated from SEBAL model and observed in K67, K83 and K77 LBA sites. The period of moving average is equal to 4 . 
Figures 15 and 16 compare the seasonal variations in $\mathrm{Rn}$ and $\mathrm{Rn}_{24 \mathrm{~h}}$ estimated from SEBAL model against the ground measurements over K67, K83 and K77 LBA sites. Although there are some differences of magnitude, which were explained before in terms of biases and RMSE, we can notice, in general, that our methodology was adequate to obtain the correct seasonal pattern of $\mathrm{Rn}$ and $\mathrm{Rn}_{24 \mathrm{~h}}$ in the Amazon region. For both $\mathrm{Rn}$ and $\mathrm{Rn}_{24 \mathrm{~h}}$, we highlight that the major discrepancy between the observed and estimated seasonal signal was found in K77 site. For the three study sites, it is clearly verified the trend of increase in the energy available at the surface to be converted to ground, sensible and latent heat fluxes during the dry season in comparison with wet season. As discussed in Section 3.1, this fact is strongly related to the seasonal variation of incoming solar radiation over the region $[64,65]$.
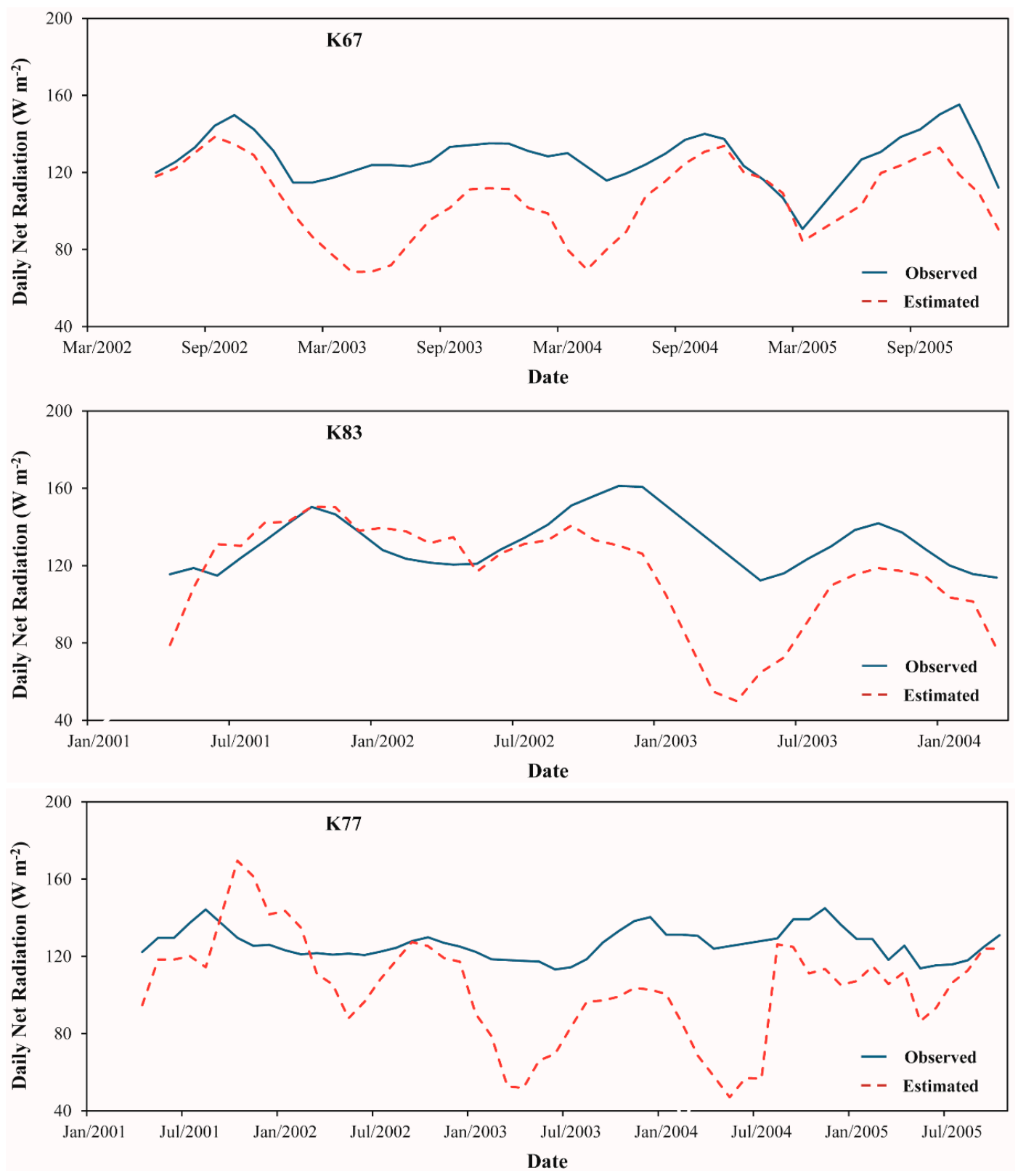

Figure 16. Moving average of the monthly cycle of daily net radiation estimated from SEBAL model and observed in K67, K83 and K77 LBA sites. The period of moving average is equal to 4. 


\section{Conclusions}

In the present study, we developed an approach to estimate net radiation and its components under all-sky conditions at a regional scale in Amazonia using only reanalysis and remotely sensed data. Our approach aimed to eliminate the need for ground observations as model input, given the difficult to obtain such information in the Amazon region. The proposition of generating monthly composites of each variable was adequate to minimize the problem related to strong cloudiness over the region and allowed to map consistently the spatial distribution of net radiation components in the eastern part of Amazonia. In general, the spatial variation of Rn was related to the larger presence of forested areas in Upper Tapajos River basin (western flank) in comparison with Curua-Una River basin (eastern flank). Temporally, Rn have shown a strongly seasonal pattern, varying according with dry and wet seasons in the region. There is a pattern of declining of cloud cover during the dry season in Amazonia and it is directly associated with the increase in incoming shortwave radiation. We highlight that it occurred as expected due to the fact of incoming solar radiation is the main controller of Rn in the region.

Regarding the dynamic of Rn under different land cover types, the results showed, overall, that the primary forest has in long-term average a higher Rn value in comparison with pasture and agriculture, which is consistent with several meteorological studies performed in the region. It is important to note that the secondary forest presented an Rn value very close to the primary forest, showing that the preservation of these areas could serve to reduce the impact of the deforestation in the climatology of Amazonia. In addition, these results show that the use of MODIS and GLDAS data allowed discriminating, in terms of magnitude and temporal behavior, different land cover types in the region.

The reanalysis products presented errors from $3.9 \%$ to $19.5 \%$ in relation to the ground measurements, suggesting that these data were an adequate alternative as model input to estimate the surface radiation budget in the region. Comparison between estimates obtained by the proposed method and observations from the LBA towers showed errors between $12.5 \%$ and $16.4 \%$ and $11.3 \%$ and $15.9 \%$ for instantaneous and daily Rn, respectively. In order to enhance the accuracy of the present methodology, future effort should focus on reducing the errors in the estimation of albedo and $L \downarrow$.

We conclude that the integration of reanalysis products and satellite data, eliminating the need for surface measurements as input model, was a useful proposition for the spatialization of the radiation fluxes in the Amazon region, which may serve as input information needed by algorithms that aim to determine evapotranspiration, the most important component of the Amazon hydrological balance.

Acknowledgments: We gratefully acknowledge all the people involved in LBA project who worked in the field data collection. Gabriel de Oliveira acknowledges the Brazilian Ministry of Science and Technology and Brazilian Ministry of Education for providing research fellowships through the CNPq (Grant No. 52521/2012-7) and CAPES (Grant No. 8210/2014-4) agencies, respectively. Luiz E. O. C. Aragão acknowledges the support of FAPESP (Grant No. 50533-5) and CNPq (Grant No. 304425/2013-3) agencies.

Author Contributions: Gabriel de Oliveira, Nathaniel A. Brunsell and Elisabete C. Moraes designed the research. Gabriel de Oliveira, Gabriel Bertani, and Thiago V. dos Santos processed the data. Gabriel de Oliveira, Nathaniel A. Brunsell, Elisabete C. Moraes, Yosio E. Shimabukuro and Luiz E. O. C. Aragão analyzed the results. Gabriel de Oliveira and Nathaniel A. Brunsell wrote the paper.

Conflicts of Interest: The authors declare no conflict of interest.

\section{References}

1. Nepstad, D.C.; Stickler, C.M.; Soares-Filho, B.; Merry, F. Interactions among Amazon land use, forests and climate: Prospects for a near-term forest tipping point. Philos. Trans. R. Soc. B 2008, 1498, 1737-1746. [CrossRef] [PubMed]

2. Egler, M.; Egler, C.A.G.; Franz, B.; de Araujo, M.S.M.; de Freitas, M.A.V. Indicators of Deforestation in the Southern Brazilian Pre-Amazon. Reg. Environ. Chang. 2013, 2, 263-271. [CrossRef] 
3. Gash, J.H.; Huntingford, C.; Marengo, J.A.; Betts, R.A.; Cox, P.M.; Fisch, G.; Fu, R.; Gandu, A.W.; Harris, P.P.; Machado, L.A.T.; et al. Amazonian climate: Results and future research. Theor. Appl. Climatol. 2004, 78, 187-193. [CrossRef]

4. Werth, D.; Avissar, R. The local and global effects of Amazon deforestation. J. Geophys. Res. Atmos. 2002, 107, 1-8. [CrossRef]

5. Aragão, L.E.; Poulter, B.; Barlow, J.B.; Anderson, L.O.; Malhi, Y.; Saatchi, S.; Phillips, O.L.; Gloor, E. Environmental change and the carbon balance of Amazonian forests. Biol. Rev. 2014, 4, 913-931. [CrossRef] [PubMed]

6. Bastiaanssen, W.G.M.; Menenti, M.; Feddes, R.A.; Holtslag, A.A.M. A remote sensing surface energy balance algorithm for land (SEBAL). 1. Formulation. J. Hydrol. 1998, 212, 198-212. [CrossRef]

7. Bisht, G.; Bras, R.L. Estimation of net radiation from the MODIS data under all sky conditions: Southern Great Plains case study. Remote Sens. Environ. 2010, 7, 1522-1534. [CrossRef]

8. Bisht, G.; Venturini, V.; Islam, S.; Jiang, L.E. Estimation of the net radiation using MODIS (Moderate Resolution Imaging Spectroradiometer) data for clear sky days. Remote Sens. Environ. 2005, 1, 52-67. [CrossRef]

9. Hou, J.; Jia, G.; Zhao, T.; Wang, H.; Tang, B. Satellite-based estimation of daily average net radiation under clear-sky conditions. Adv. Atmos. Sci. 2014, 3, 705-720. [CrossRef]

10. Fisher, J.B.; Malhi, Y.; Bonal, D.; da Rocha, H.R.; de Araujo, A.C.; Gamo, M.; Goulden, M.L.; Hirano, T.; Huete, A.R.; Kondo, H.; et al. The land-atmosphere water flux in the tropics. Glob. Chang. Biol. 2009, 11, 2694-2714. [CrossRef]

11. Baker, I.T.; Harper, A.B.; da Rocha, H.R.; Denning, A.S.; Araújo, A.C.; Borma, L.S.; Freitas, H.C.; Goulden, M.L.; Manzi, A.O.; Miller, S.D.; et al. Surface ecophysiological behavior across vegetation and moisture gradients in tropical South America. Agric. For. Meteorol. 2013, 182, 177-188. [CrossRef]

12. Shuttleworth, W.J. Evaporation from Amazonian rainforest. Proc. R. Soc. Lond. B 1988, 1272, 321-346. [CrossRef]

13. Garstang, M.; Greco, S.; Scala, J.; Swap, R.; Ulanski, S.; Fitzjarrald, D.; Martin, D.; Browell, E.; Shipman, M.; Connors, V.; et al. The Amazon boundary-layer experiment (ABLE 2B): A meteorological perspective. Bull. Am. Meteorol. Soc. 1990, 1, 19-32. [CrossRef]

14. Gash, J.H.C.; Nobre, C.A. Climatic effects of Amazonian deforestation: Some results from ABRACOS. Bull. Am. Meteorol. Soc. 1997, 5, 823-830. [CrossRef]

15. Martin, S.T.; Artaxo, P.; Machado, L.A.T.; Manzi, A.O.; Souza, R.A.F.; Schumacher, C.; Wang, J.; Andreae, M.O.; Barbosa, H.M.J.; Fan, J.; et al. Introduction: Observations and Modeling of the Green Ocean Amazon (GoAmazon2014/5). Atmos. Chem. Phys. 2015, 21, 30175-30210. [CrossRef]

16. Artaxo, P. Break down boundaries in climate research. Nature 2012, 7381, 239. [CrossRef] [PubMed]

17. Gonçalves, L.G.G.; Borak, J.S.; Costa, M.H.; Saleska, S.R.; Baker, I.; Restrepo-Coupe, N.; Muza, M.N.; Poulter, B.; Verbeeck, H.; Fisher, J.B.; et al. Overview of the large-scale biosphere-atmosphere experiment in Amazonia Data Model Intercomparison Project (LBA-DMIP). Agric. For. Meteorol. 2013, 182, 111-127. [CrossRef]

18. Martínez, B.; Gilabert, M.A. Vegetation dynamics from NDVI time series analysis using the wavelet transform. Remote Sens. Environ. 2009, 9, 1823-1842. [CrossRef]

19. Bontemps, S.; Herold, M.; Kooistra, L.; van Groenestijn, A.; Hartley, A.; Arino, O.; Moreau, I.; Defourny, P. Revisiting land cover observations to address the needs of the climate modelling community. Biogeosciences 2012, 6, 2145-2157. [CrossRef]

20. Gong, P.; Wang, J.; Yu, L.; Zhao, Y.; Zhao, Y.; Liang, L.; Niu, Z.; Huang, X.; Fu, H.; Liu, S.; et al. Finer resolution observation and monitoring of global land cover: First mapping results with Landsat TM and ETM+ data. Int. J. Remote Sens. 2013, 7, 2607-2654. [CrossRef]

21. Yang, J.; Gong, P.; Fu, R.; Zhang, M.; Chen, J.; Liang, S.; Xu, B.; Shi, J.; Dickinson, R. The role of satellite remote sensing in climate change studies. Nat. Clim. Chang. 2013, 10, 875-883. [CrossRef]

22. Zhong, M.; Weill, A.; Taconet, O. Estimation of net radiation and surface heat fluxes using NOAA-7 satellite infrared data during fair-weather cloudy situations of MESOGERS-84 experiment. Boun. Layer Meteorol. 1990, 4, 353-370. [CrossRef]

23. Samani, Z.; Bawazir, A.S.; Bleiweiss, M.; Skaggs, R.; Tran, V.D. Estimating daily net radiation over vegetation canopy through remote sensing and climatic data. J. Irrig. Drain. Eng. 2007, 4, 291-297. [CrossRef] 
24. Kim, H.Y.; Liang, S. Development of a hybrid method for estimating land surface shortwave net radiation from MODIS data. Remote Sens. Environ. 2010, 11, 2393-2402. [CrossRef]

25. Fausto, M.A.; Machado, N.G.; de Souza Nogueira, J.; Biudes, M.S. Net radiation estimated by remote sensing in Cerrado areas in the Upper Paraguay River Basin. J. Appl. Remote Sens. 2014, 1, 1-17. [CrossRef]

26. Wang, D.; Liang, S.; He, T.; Shi, Q. Estimating clear-sky all-wave net radiation from combined visible and shortwave infrared (VSWIR) and thermal infrared (TIR) remote sensing data. Remote Sens. Environ. 2015, 167, 31-39. [CrossRef]

27. Wang, Y.; Tian, Y.; Zhang, Y.; El-Saleous, N.; Knyazikhin, Y.; Vermote, E.; Myneni, R.B. Investigation of product accuracy as a function of input and model uncertainties: Case study with SeaWiFS and MODIS LAI/FPAR algorithm. Remote Sens. Environ. 2001, 3, 299-313. [CrossRef]

28. Schroeder, T.A.; Hember, R.; Coops, N.C.; Liang, S. Validation of solar radiation surfaces from MODIS and reanalysis data over topographically complex terrain. J. Appl. Meteorol. Climatol. 2009, 12, 2441-2458. [CrossRef]

29. Liang, S.; Wang, K.; Zhang, X.; Wild, M. Review on estimation of land surface radiation and energy budgets from ground measurement, remote sensing and model simulations. IEEE J. Sel. Top. Appl. Earth Obs. Remote Sens. 2010, 3, 225-240. [CrossRef]

30. Jin, Y.; Randerson, J.T.; Goulden, M.L. Continental-scale net radiation and evapotranspiration estimated using MODIS satellite observations. Remote Sens. Environ. 2011, 9, 2302-2319. [CrossRef]

31. Shi, Q.; Liang, S. Characterizing the surface radiation budget over the Tibetan Plateau with ground-measured, reanalysis, and remote sensing data sets: 2. Spatiotemporal analysis. J. Geophys. Res. Atmos. 2013, 16, 8921-8934. [CrossRef]

32. Kalnay, E.; Kanamitsu, M.; Kistler, R.; Collins, W.; Deaven, D.; Gandin, L.; Iredell, M.; Saha, S.; White, G.; Woollen, J.; et al. The NCEP/NCAR 40-year reanalysis project. Bull. Am. Meteorol. Soc. 1996, 3, 437-471. [CrossRef]

33. Rodell, M.; Houser, P.R.; Jambor, U.E.A.; Gottschalck, J.; Mitchell, K.; Meng, C.J.; Arsenault, K.; Cosgrove, B.; Radakovich, J.; Bosilovich, M.; et al. The global land data assimilation system. Bull. Am. Meteorol. Soc. 2004, 3, 381-394. [CrossRef]

34. Sheffield, J.; Goteti, G.; Wood, E.F. Development of a 50-year high-resolution global dataset of meteorological forcings for land surface modeling. J. Clim. 2006, 13, 3088-3111. [CrossRef]

35. Santos, C.C.D.; Nascimento, R.L.; Rao, T.V.R.; Manzi, A.O. Net radiation estimation under pasture and forest in Rondônia, Brazil, with TM Landsat 5 images. Atmosfera 2011, 4, 435-446.

36. Oliveira, G.; Moraes, E. Validation of net radiation obtained through MODIS/TERRA data in Amazonia with LBA surface measurements. Acta Amazon. 2013, 3, 353-364. [CrossRef]

37. Eidt, R.C. The Climatology of South América. In Biogegraphy and Ecology in South America; Fittkau, E.J., Illies, J., Klinge, H., Schwabe, G.H., Sioli, J.C.H., Eds.; Dr. W. Junk: The Hague, The Netherlands, 1968; pp. 54-81.

38. Lola, A.C.; Uchoa, P.W.; Júnior, J.A.S.; Cunha, A.C.; Feitosa, J.R.P. Term-hygrometric variations and influences of process of urban expansion in a city of equatorial midsize. Braz. Geogr. J. Geosci. Hum. Res. Med. 2013, 2, 615-632.

39. Saleska, S.R.; Miller, S.D.; Matross, D.M.; Goulden, M.L.; Wofsy, S.C.; da Rocha, H.R.; de Camargo, P.B.; Crill, P.; Daube, B.C.; de Freitas, H.C.; et al. Carbon in Amazon forests: Unexpected seasonal fluxes and disturbance-induced losses. Science 2003, 5650, 1554-1557. [CrossRef] [PubMed]

40. Silver, W.L.; Neff, J.; McGroddy, M.; Veldkamp, E.; Keller, M.; Cosme, R. Effects of soil texture on belowground carbon and nutrient storage in a lowland Amazonian forest ecosystem. Ecosystems 2000, 2, 193-209. [CrossRef]

41. Telles, E.D.C.C.; de Camargo, P.B.; Martinelli, L.A.; Trumbore, S.E.; da Costa, E.S.; Santos, J.; Higuchi, N.; Oliveira, R.C. Influence of soil texture on carbon dynamics and storage potential in tropical forest soils of Amazonia. Glob. Biogeochem. Cycles 2003, 2, 1-12. [CrossRef]

42. Hunter, M.O.; Keller, M.; Victoria, D.; Morton, D.C. Tree height and tropical forest biomass estimation. Biogeosciences 2013, 12, 8385-8399. [CrossRef]

43. Hutyra, L.R.; Munger, J.W.; Saleska, S.R.; Gottlieb, E.; Daube, B.C.; Dunn, A.L.; Amaral, D.F.; de Camargo, P.B.; Wofsy, S.C. Seasonal controls on the exchange of carbon and water in an Amazonian rain forest. J. Geophys. Res. Biogeosci. 2007, 112, 1-16. [CrossRef] 
44. Miller, S.D.; Goulden, M.L.; da Rocha, H.R. The effect of canopy gaps on subcanopy ventilation and scalar fluxes in a tropical forest. Agric. For. Meteorol. 2007, 1, 25-34. [CrossRef]

45. Restrepo-Coupe, N.; da Rocha, H.R.; Hutyra, L.R.; da Araujo, A.C.; Borma, L.S.; Christoffersen, B.; Cabral, O.M.; de Camargo, P.B.; Cardoso, F.L.; da Costa, A.C.L.; et al. What drives the seasonality of photosynthesis across the Amazon basin? A cross-site analysis of eddy flux tower measurements from the Brasil flux network. Agric. For. Meteorol. 2013, 182, 128-144. [CrossRef]

46. Sakai, R.K.; Fitzjarrald, D.R.; Moraes, O.L.; Staebler, R.M.; Acevedo, O.C.; Czikowsky, M.J.; Silva, R.D.; Brait, E.; Miranda, V. Land-use change effects on local energy, water, and carbon balances in an Amazonian agricultural field. Glob. Chang. Biol. 2004, 5, 895-907. [CrossRef]

47. Rice, A.H.; Pyle, E.H.; Saleska, S.R.; Hutyra, L.; Palace, M.; Keller, M.; de Camargo, P.B.; Portilho, K.; Marques, D.F.; Wofsy, S.C. Carbon balance and vegetation dynamics in an old-growth Amazonian forest. Ecol. Appl. 2005, 14, 55-71. [CrossRef]

48. Miller, S.D.; Goulden, M.L.; Hutyra, L.R.; Keller, M.; Saleska, S.R.; Wofsy, S.C.; Figueira, A.M.S.; da Rocha, H.R.; de Camargo, P.B. Reduced impact logging minimally alters tropical rainforest carbon and energy exchange. Proc. Natl. Acad. Sci. USA 2011, 48, 19431-19435. [CrossRef] [PubMed]

49. Coutinho, A.C.; Almeida, C.; Venturieri, A.; Esquerdo, J.C.D.M.; Silva, M. Land Use and Land Cover in Deforested Areas of Brazilian Legal Amazon: TerraClass 2008; Livros Cientificos: Brasilia, Brazil, 2008; pp. 1-107.

50. Ruhoff, A.L.; Paz, A.R.; Collischonn, W.; Aragao, L.E.; Rocha, H.R.; Malhi, Y.S. A MODIS-based energy balance to estimate evapotranspiration for clear-sky days in Brazilian tropical savannas. Remote Sens. 2012, 3, 703-725. [CrossRef]

51. Ruhoff, A.L.; Paz, A.R.; Aragao, L.E.O.C.; Mu, Q.; Malhi, Y.; Collischonn, W.; Running, S.W. Assessment of the MODIS global evapotranspiration algorithm using eddy covariance measurements and hydrological modelling in the Rio Grande basin. Hydrol. Sci. J. 2013, 8, 1658-1676. [CrossRef]

52. Justice, C.O.; Townshend, J.R.G.; Vermote, E.F.; Masuoka, E.; Wolfe, R.E.; Saleous, N.; Roy, D.P.; Morisette, J.T. An overview of MODIS Land data processing and product status. Remote Sens. Environ. 2002, 1, 3-15. [CrossRef]

53. Wolfe, R.E.; Nishihama, M.; Fleig, A.J.; Kuyper, J.A.; Roy, D.P.; Storey, J.C.; Patt, F.S. Achieving sub-pixel geolocation accuracy in support of MODIS land science. Remote Sens. Environ. 2002, 1, 31-49. [CrossRef]

54. Wolfe, R.E.; Roy, D.P.; Vermote, E. MODIS land data storage, gridding, and compositing methodology: Level 2 grid. IEEE Trans. Geosci. Remote Sens. 1998, 4, 1324-1338. [CrossRef]

55. Koren, V.; Schaake, J.; Mitchell, K.; Duan, Q.Y.; Chen, F.; Baker, J.M. A parameterization of snowpack and frozen ground intended for NCEP weather and climate models. J. Geophys. Res. Atmos. 1999, 104, 19569-19585. [CrossRef]

56. Allen, R.G.; Tasumi, M.; Trezza, R. SEBAL (Surface Energy Balance Algorithms for Land) Advanced Training and User's Manual-Idaho Implementation. Idaho University: Moscow, ID, USA, 2002; Idaho University: Moscow, ID, USA, 2002; 1-98.

57. Bastiaanssen, W.G.M.; Noordman, E.J.M.; Pelgrum, H.; Davids, G.; Thoreson, B.P.; Allen, R.G. SEBAL model with remotely sensed data to improve water-resources management under actual field conditions. J. Irrig. Drain. Eng. 2005, 1, 85-93. [CrossRef]

58. Liang, S. Narrowband to broadband conversions of land surface albedo I: Algorithms. Remote Sens. Environ. 2001, 2, 213-238. [CrossRef]

59. Eidenshink, J. The 1990 conterminous U.S. AVHRR data set. Photogramm. Eng. Remote Sens. 1992, 6, 809-813.

60. Huete, A.R. A soil-adjusted vegetation index (SAVI). Remote Sens. Environ. 1988, 3, 295-309. [CrossRef]

61. Xiao, X.; Zhang, Q.; Braswell, B.; Urbanski, S.; Boles, S.; Wofsy, S.; Moore, B.; Ojima, D. Modeling gross primary production of temperate deciduous broadleaf forest using satellite images and climate data. Remote Sens. Environ. 2004, 2, 256-270. [CrossRef]

62. Baik, J.; Choi, M. Evaluation of remotely sensed actual evapotranspiration products from COMS and MODIS at two different flux tower sites in Korea. Int. J. Remote Sens. 2015, 1, 375-402. [CrossRef]

63. Liu, Z.; Shao, Q.; Liu, J. The performances of MODIS-GPP and-ET products in China and their sensitivity to input data (FPAR/LAI). Remote Sens. 2015, 1, 135-152. [CrossRef]

64. Salati, E.; Marques, J. Climatology of the Amazon Region. In The Amazon; Sioli, H., Ed.; Springer: Rotterdam, The Netherlands, 1984; pp. 85-126. 
65. Malhi, Y.; Pegoraro, E.; Nobre, A.D.; Pereira, M.G.P.; Grace, J.; Culf, A.D.; Clement, R. Energy and water dynamics of a central Amazonian rain forest. J. Geophys. Res. Atmos. 2002, 107, 1-17. [CrossRef]

66. Schafer, J.S.; Eck, T.F.; Holben, B.N.; Artaxo, P.; Yamasoe, M.A.; Procopio, A.S. Observed reductions of total solar irradiance by biomass-burning aerosols in the Brazilian Amazon and Zambian Savanna. Geophys. Res. Lett. 2002, 17, 1-4. [CrossRef]

67. Zhang, Y.; Fu, R.; Yu, H.; Dickinson, R.E.; Juarez, R.N.; Chin, M.; Wang, H. A regional climate model study of how biomass-burning aerosol impacts land-atmosphere interactions over the Amazon. J. Geophys. Res. 2008, 113. [CrossRef]

68. Rocha, H.R.; Goulden, M.L.; Miller, S.D.; Menton, M.C.; Pinto, L.D.; de Freitas, H.C.; Silva Figueira, A.M. Seasonality of water and heat fluxes over a tropical forest in eastern Amazonia. Ecol. Appl. 2004, 14, $22-32$. [CrossRef]

69. Marengo, J.A.; Nobre, C.A.; Tomasella, J.; Oyama, M.D.; Sampaio de Oliveira, G.; De Oliveira, R.; Brown, I.F. The drought of Amazonia in 2005. J. Clim. 2008, 3, 495-516. [CrossRef]

70. Zeng, N.; Yoon, J.H.; Marengo, J.A.; Subramaniam, A.; Nobre, C.A.; Mariotti, A.; Neelin, J.D. Causes and impacts of the 2005 Amazon drought. Environ. Res. Lett. 2008, 1, 014002. [CrossRef]

71. Von Randow, C.; Manzi, A.O.; Kruijt, B.; De Oliveira, P.J.; Zanchi, F.B.; Silva, R.L.; Hodnett, M.G.; Gash, J.H.C.; Elbers, J.A.; Waterloo, M.J.; et al. Comparative measurements and seasonal variations in energy and carbon exchange over forest and pasture in South West Amazonia. Theor. Appl. Climatol. 2004, 78, 5-26. [CrossRef]

72. Lambin, E.F.; Geist, H.J.; Lepers, E. Dynamics of land-use and land-cover change in tropical regions. Annu. Rev. Environ. Resour. 2003, 1, 205-241. [CrossRef]

73. Skole, D.; Tucker, C. Tropical deforestation and habitat fragmentation in the Amazon. Satellite data from 1978 to 1988. Science 1993, 5116, 1905-1910. [CrossRef] [PubMed]

74. Gash, J.H.; Shuttleworth, W.J. Tropical deforestation: Albedo and the surface-energy balance. Clim. Chang. 1991, 19, 123-133. [CrossRef]

75. Bastable, H.G.; Shuttleworth, W.J.; Dallarosa, R.L.G.; Fisch, G.; Nobre, C.A. Observations of climate, albedo, and surface radiation over cleared and undisturbed Amazonian forest. Int. J. Climatol. 1993, 7, 783-796. [CrossRef]

76. Culf, A.D.; Fisch, G.; Hodnett, M.G. The albedo of Amazonian forest and ranch land. J. Clim. 1995, 6, 1544-1554. [CrossRef]

77. Priante-Filho, N.; Vourlitis, G.L.; Hayashi, M.M.S.; Nogueira, J.D.S.; Campelo, J.H.; Nunes, P.C.; Souza, L.S.E.; Couto, E.G.; Hoeger, W.; Raiter, F.; et al. Comparison of the mass and energy exchange of a pasture and a mature transitional tropical forest of the southern Amazon Basin during a seasonal transition. Glob. Chang. Biol. 2004, 5, 863-876. [CrossRef]

78. Souza Filho, J.D.C.; Ribeiro, A.; Costa, M.H.; Cohen, J.C.P.; Rocha, E.J.P. Seasonal variation of the radiation balance in a northeast Amazonian Rainforest. Braz. J. Meteorol. 2006, 3, 318-330.

79. Aguiar, L.J.G.; Costa, J.M.N.D.; Fisch, G.R.; Aguiar, R.G.; Costa, A.C.L.D.; Ferreira, W.P.M. Estimate of the atmospheric longwave radiation in forest and pasture areas in southwest Amazon. Braz. J. Meteorol. 2011, 2, 211-224.

80. Davidson, E.A.; de Araújo, A.C.; Artaxo, P.; Balch, J.K.; Brown, I.F.; Bustamante, M.M.; Coe, M.T.; DeFries, R.S.; Keller, M.; Longo, M.; et al. The Amazon Basin in transition. Nature 2012, 7381, 321-328. [CrossRef] [PubMed]

81. Culf, A.D.; Esteves, J.L.; Marques Filho, A.D.O.; da Rocha, H.R. Radiation, Temperature and Humidity over Forest and Pasture in Amazonia. In Amazonian Deforestation and Climate; Gash, J.H.C., Nobre, C.A., Roberts, J.M., Victoria, R.L., Eds.; John Wiley \& Sons: Chichester, UK, 1996; pp. 175-192.

82. Fisch, G.; Marengo, J.A.; Nobre, C.A. The climate of Amazonia: A review. Acta Amazon. 1998, 2, $101-126$. [CrossRef]

83. Costa, M.H.; Biajoli, M.C.; Sanches, L.; Malhado, A.; Hutyra, L.R.; da Rocha, H.R.; Aguiar, R.G.; de Araújo, A.C. Atmospheric versus vegetation controls of Amazonian tropical rain forest evapotranspiration: Are the wet and seasonally dry rain forests any different? J. Geophys. Res. Biogeosci. 2010, 115, 1-9. [CrossRef]

84. Wright, I.R.; Gash, J.H.C.; da Rocha, H.R.; Shuttleworth, W.J.; Nobre, C.A.; Maitelli, G.T.; Zamparoni, C.A.G.P.; Carvalho, P.R.A. Dry season micrometeorology of central Amazonian ranchland. Q. J. R. Meteorol. Soc. 1992, 508, 1083-1099. [CrossRef] 
85. Galvão, J.D.C.; Fisch, G. Energy balance in forest and pasture areas in Amazonia (Ji-Parana, RO). Braz. J. Meteorol. 2000, 2, 25-37.

86. Aguiar, L.J.G. Radiation Balance over Forest and Pasture Areas in Rondonia. M.Sc. Dissertation, Federal University of Vicosa, Vicosa, Brazil, 2007.

87. Nobre, C.A.; Sellers, P.J.; Shukla, J. Amazonian deforestation and regional climate change. J. Clim. 1991, 10, 957-988. [CrossRef]

88. Manzi, A.O.; Planton, S. A Simulation Amazonian Deforestation Using a GCM Calibrated with ABRACOS and ARME Data. In Amazonian Deforestation and Climate; Gash, J.H.C., Nobre, C.A., Roberts, J.M., Victoria, R.L., Eds.; John Wiley \& Sons: Chichester, UK, 1996; pp. 503-529.

89. Cardoso, M.; Nobre, C.; Sampaio, G.; Hirota, M.; Valeriano, D.; Câmara, G. Long-term potential for tropical-forest degradation due to deforestation and fires in the Brazilian Amazon. Biologia 2009, 3, 433-437. [CrossRef]

90. Bisht, G.; Bras, R.L. Estimation of net radiation from the moderate resolution imaging spectroradiometer over the continental United States. IEEE Trans. Geosci. Remote Sens. 2011, 6, 2448-2462. [CrossRef]

91. Darnell, W.L.; Gupta, S.K.; Staylor, W.F. Downward longwave radiation at the surface from satellite measurements. J. Clim. Appl. Meteorol. 1983, 11, 1956-1960. [CrossRef]

92. Tang, B.; Li, Z.L. Estimation of instantaneous net surface longwave radiation from MODIS cloud-free data. Remote Sens. Environ. 2008, 9, 3482-3492. [CrossRef]

93. Wang, W.; Liang, S. Estimation of high-spatial resolution clear-sky longwave downward and net radiation over land surfaces from MODIS data. Remote Sens. Environ. 2009, 4, 745-754. [CrossRef]

94. Kim, J.; Hogue, T.S. Evaluation of a MODIS-based potential evapotranspiration product at the point scale. J. Hydrometeorol. 2008, 3, 444-460. [CrossRef]

(C) 2016 by the authors; licensee MDPI, Basel, Switzerland. This article is an open access article distributed under the terms and conditions of the Creative Commons Attribution (CC-BY) license (http://creativecommons.org/licenses/by/4.0/). 